\title{
Comparison of the Species Communities of Phytophthora, Pythium, and Phytopythium Associated with Soybean Genotypes in High Disease Environments in Ohio
}

\author{
Krystel A. Navarro, ${ }^{1,4}$ Saranga Wijeratne, ${ }^{2}$ Steve Culman, ${ }^{3}$ Maria-Soledad Benitez, ${ }^{1}$ and Anne E. Dorrance ${ }^{1,4, \dagger}$ \\ ${ }^{1}$ Department of Plant Pathology, The Ohio State University OARDC, Wooster, OH 44691 \\ ${ }^{2}$ Molecular and Cellular Imaging Center, The Ohio State University OARDC, Wooster, $\mathrm{OH} 44691$ \\ ${ }^{3}$ School of Environment and Natural Resources, The Ohio State University, Wooster, $\mathrm{OH} 44601$ \\ ${ }^{4}$ Center for Applied Plant Sciences and Center for Soybean Research, The Ohio State University, Columbus, $\mathrm{OH} 43210$
}

Accepted for publication 28 February 2021.

\section{ABSTRACT}

The roles that specific cultivars with different levels and types of resistance may play on the diversity and abundance of Phytophthora, Phytopythium, and Pythium spp. communities were compared. Three soybean cultivars were planted in a total of 11 different high disease environments in Ohio and seedlings were collected for direct isolation and amplicon sequencing of the rhizosphere soil. Plant population and yields were lower for the moderately susceptible cultivar Sloan compared with the cultivars Kottman, with high partial resistance to Phytophthora sojae, and Lorain, with high partial resistance to both Pythium spp. and Phytophthora sojae. Based on both direct isolation and amplicon sequencing, distinct communities with key indicator species were identified at each environment, including differences at 14 and 25 day after planting for two environments. The environment had the largest influence on the community composition. Soybean genotype did influence the abundance of the hemibiotroph Phytophthora sojae but not species of Phytopythium or Pythium. In addition, from all environments and cultivars, operational taxonomic units (OTUs) classified as Pythium attrantheridium, $P$. heterothallicum, and $P$. sylvaticum were always detected. This is also the first report of an OTU of $P$. periilum from soils and the first one to recover undescribed species that match the sequence of Pythium sp. CAL2011f from soybean seedlings in Ohio This study highlights which species to target for the identification and development of resistant cultivars or for fungicide screening.

Keywords: amplicon sequencing, oomycetes, Phytophthora, Pythium, species complex
Disease management of soybean seedling diseases caused by species of Phytophthora (Kroon et al. 2012), Phytopythium (de Cock et al. 2015), and Pythium (including Globisporangium) (Adhikari et al. 2013; Schroeder et al. 2013; Uzuhashi et al. 2010) can be

†Corresponding author: A. E. Dorrance; dorrance.1@osu.edu

Funding: This project was supported, in part, by The Ohio State University Graduate School through the Summer Research Opportunity Program to K. NavarroAcevedo, Syngenta Crop Protection, and the Ohio Soybean Council. Salaries and research support for this project were provided by State and Federal Funds appropriated to The Ohio State University Ohio Agricultural Research and Development Center Seeds Grant Program and the United States Department of AgricultureNational Institute of Food and Agriculture, Hatch project Development of Disease Management Strategies for Soybean Pathogens in Ohio (OH001303).

*The $\boldsymbol{e}$-Xtra logo stands for "electronic extra" and indicates that a supplementary figure and supplementary tables are published online.

The author(s) declare no conflict of interest.

(C) 2021 The American Phytopathological Society challenging for several reasons: (i) more than one species can be recovered from the same seedling (Broders et al. 2009; ZitnickAnderson and Nelson 2015), (ii) the diversity of pathotypes observed in Phytophthora sojae (Dorrance et al. 2016), and (iii) similarities of the internal transcribed spacer (ITS) sequence of some Pythium spp. within some clades of Pythium which are classified as species complexes or cryptic species (Garzón et al. 2005; Lévesque and de Cock 2004; Schroeder et al. 2013).

Several surveys have recovered a vast diversity of Pythium spp. from soybean and corn seedlings across major soybean-producing states in the United States and Canada (Dorrance et al. 2004; Broders et al. 2007; Broders et al. 2009; Jiang et al. 2012; Radmer et al. 2017; Rojas et al. 2017a, 2019; Zitnick-Anderson and Nelson 2015). Pythium sylvaticum, $P$. irregulare, $P$. ultimum. and $P$. heterothallicum were among the most frequently recovered species. Among Phytophthora spp., Phytophthora sojae primarily infects soybean and can also cause stem rot throughout the season (Dorrance et al. 2007) and has been recovered from soybean seedlings directly baited from soils in fields across the North-Central region of the United States (Dorrance et al. 2016), whereas isolates of Phytophthora 
sansomeana are less common and have been recovered from a greater number of hosts, including Douglas-fir, soybean, and alfalfa in Oregon (Hansen et al.2009); soybean in Indiana (Reeser et al. 1991); and corn and soybean in Ohio (Eyre 2016; Vargas 2018; Zelaya-Molina et al. 2010). Similarly, species of Phytopythium have also been recovered from soybean seedlings in fields in Ohio (Broders et al. 2009; Eyre 2016; Vargas 2018), Minnesota (Radmer et al. 2017), and other states, including Arkansas, Illinois, Indiana, Iowa, Nebraska, Minnesota, and South Dakota (Rojas et al. 2017a).

Previous surveys in Ohio identified a diversity of species through soil baiting and direct isolation. For example, in total, 124 isolates was recovered from symptomatic corn and soybean seedlings collected from 40 locations in Ohio in 2004, and 30 locations in Ohio and 2 locations in northeast Indiana in 2005 (Broders et al. 2007). There were 11 different Pythium spp. recovered, with $P$. dissotocum and $P$. sylvaticum as the most prevalent, representing 23 and $20 \%$ of the isolates, respectively. In a second survey, more than 7,000 isolates were baited from soils incubated at $18^{\circ} \mathrm{C}$ and 21 different species of Pythium were recovered, with 6 species recovered from more than $40 \%$ of the fields (Broders et al. 2009). P. irregulare was the most abundant, along with $P$. inflatum, $P$. ultimum var. ultimum, $P$. ultimum var. sporangiiferum, $P$. torulosum, and $P$. dissotocum (Broders et al. 2009). During 2014 to 2016, the species $P$. ultimum var. ultimum and $P$. oopapillum were recovered at a higher proportion while other species such as $P$. torulosum, $P$. middletonii, $P$. inflatum, and $P$. dissotocum were also recovered but not consistently across years (Eyre 2016; Vargas 2018). Thus, the observed changes in the predominant species of oomycetes among these surveys suggest that environment may be an important factor driving community composition.

To better manage seed and seedling diseases caused by these soilborne pathogens, an integrated disease management approach is recommended. This includes the combination of fungicide seed treatment paired with host resistance (Anderson and Buzzell 1982; Bradley 2008; Dorrance et al. 2004, 2009; Urrea et al. 2017). Fungicide efficacy is variable among several of these species and host resistance has shown to be the best means of management in regions where there are high levels of inoculum and conducive environments (Dorrance et al. 2009; Schmitthenner 1985). In soybean, three types of resistance have been described to control Phytophthora sojae: single dominant resistance $(R)$ genes (resistance to Phytophthora sojae $[R p s]$ ), root resistance, and partial resistance (Mideros et al. 2007). In the United States, Rps genes for Phytophthora sojae are deployed to provide protection against this pathogen where most of the soybean is produced (Grau et al. 2004; Slaminko et al. 2010). However, for Pythium spp., few sources of resistance have been identified (Ellis et al. 2013; Rod et al. 2018; Rupe et al. 2011; Scott et al. 2019). Based on biparental mapping studies, partial resistance has been characterized toward several different species of Pythium (Ellis et al. 2013; Klepadlo et al. 2019; Rod et al. 2018; Rosso et al. 2008; Rupe et al. 2011; Scott et al. 2019; Stasko et al. 2016; Urrea et al. 2017).

The incorporation of genes from wild relatives into adapted cultivars has enhanced the resistance to many plant pathogens, thus increasing yield and biomass of many crops (Mammadov et al. 2018). However, plant genotype has also been proposed to affect the microbial community associated with the rhizosphere (Bulgarelli et al. 2015; Pérez-Jaramillo et al. 2016, 2017, 2019). The microorganisms that colonize the rhizosphere play a pivotal role in biogeochemical cycling, plant growth, and resistance to biotic and abiotic factors (Firáková et al. 2007; Mendes et al. 2011, 2013; Mendes et al. 2014; Philippot et al. 2013). Advances in DNA sequencing technologies and the use of amplicon sequencing has enabled researchers to explore the microbial communities at greater depth under different agricultural, natural, and experimental conditions (Bakker et al. 2017; Pérez-Jaramillo et al. 2019; Redekar et al. 2019; Rojas et al. 2019; Shi et al. 2019). For example, PérezJaramillo et al. (2019) compared the rhizobacterial communities associated with eight accessions of wild and modern common bean cultivars (Phaseolus vulgaris L.) grown in native and agricultural soils from Colombia. Soil origin (native or agricultural soils) was the key factor affecting the composition of the rhizosphere bacterial community. However, the effect of bean genotype within each soil was able to explain 31.3 and $28.3 \%$ of the total variability in the agricultural and native soils, respectively. Based on cooccurrence network analysis, more complex interactions of the rhizobacterial communities associated with common bean were found when grown under native soils compared with the agriculturally managed soils, suggesting that soil edaphic factors may also influence the overall bacterial species diversity and abundance (Pérez-Jaramillo et al. 2019). Similarly, the effect of crop domestication on rice (Oryza sativa and O. rufipogon) and soybean (Glycine max and G. soja) rhizosphere microbial community structures (Shi et al. 2019) identified a stronger association between fungal and microbial communities from cultivated rice and soybean compared with wild relatives. However, wild relatives exhibited higher abundance of beneficial symbionts and lower abundance of pathogens (Shi et al. 2019), suggesting that plant domestication might enhance the attraction or development of pathogenic species.

To date, the community composition of Phytophthora, Phytopythium, and Pythium spp. associated with cultivars with different levels and types of resistance remains unexplored, and how these genotypes affect rhizosphere community diversity remains to be elucidated. Thus, the hypotheses evaluated in this study were (i) high disease environments will support higher levels of diversity and distinct communities of Phytophthora, Phytopythium, and Pythium spp.; (ii) there will be a greater abundance and diversity of species of Phytophthora, Phytopythium, and Pythium recovered from seedlings and in the rhizosphere soil of the susceptible cultivar (Sloan) compared with the moderately resistant cultivars Kottman and Lorain; and (iii) soybean genotypes with combined resistance to Phytophthora sojae and Pythium spp. will have higher plant populations and yield across all environments. The three cultivars selected for this study (Sloan, Kottman, and Lorain) have very different combinations and levels of resistance and susceptibility toward predominant species of these pathogens. An ampliconsequencing approach paired with direct isolation were used to determine the effect of Kottman, Lorain, and Sloan on the abundance, diversity, and species composition of these three oomycete genera to address these hypotheses.

\section{MATERIALS AND METHODS}

Field experiments. To evaluate the effects of environment and cultivar on the composition of Phytophthora, Phytopythium, and Pythium communities, six and five fields were selected in 2017 and 2018, respectively. Fields used in this study were selected based on a prior history of seedling disease reported by farmers as well as at The Ohio State University (OSU) Agricultural Research Stations. The term "environment" was used to describe a single field site each year (e.g., Clinton field in 2017), for a total of 11 environments for this study. In 2017, field studies were located in Clinton (CLN17), Darke (DAK17), Defiance (DEF17), Van Wert (VW17) Wayne (SNY17), and Wood (NWB17) Counties; and, for 2018, in Clinton (CLN18), Logan (LOG18), Paulding (PAL18), Wayne (SNY18), and Wood (NWB18) Counties (Fig. 1); all in Ohio. The environments in Wood County (NWB17 and NWB18), located at OSU Northwest Agricultural Research Station, were used 
as the "control" environment because fields in both years were irrigated to capacity 2 to 3 days after planting (dap) to enhance disease development. The remaining nine environments were dependent on natural rainfall for conducive conditions for disease development.

Plant material. Resistance toward Phytophthora sojae and Pythium sp. from these soybean genotypes has been evaluated (Balk 2014; Dorrance et al. 2009; Ellis et al. 2013; Scott et al. 2019). Three soybean cultivars were selected to compare the effects of soybean genotype on the associated rhizosphere community in each environment, including Sloan (Bahrenfus and Fehr 1980), with moderate susceptibility to Phytophthora sojae and Pythium sp. and no Rps genes; Kottman (St. Martin et al. 2001), with Rpslk and Rps $3 a$ genes plus moderate resistance to Phytophthora sojae and moderate susceptibility to Pythium sp.; and Lorain (Ohio Agricultural Research and Development Center [OARDC], OSU), with Rpslc plus moderate resistance to both Phytophthora sojae and Pythium spp. (Balk 2014; Scott et al. 2019). For each environment, cultivars were planted in a randomized complete block design with eight replications each. Each field plot was planted with four rows, spaced $1.5 \mathrm{~m}$ wide and $9.1 \mathrm{~m}$ long, except for fields located at Wayne (SNY17 and SNY18) and Wood (NWB17 and NWB18) where the plot length was $7.6 \mathrm{~m}$. Data were collected for early plant population at soybean growth stages VC to V1, final plant population at R8 (Fehr and Caviness 1977), and yield (kilograms per hectare). Data for plant populations at each growth stage were measured by counting the number of plants in 91-cm sections of all four rows and translated to plants per hectare.

Seedling sampling. At soybean growth stages VC to V1, the whole plant (roots intact) of five seedlings which were wilting from lesions developing on the roots were collected from each plot from our replicates of each cultivar with a hand trowel and placed in plastic bags, which were then placed in a cooler with ice for transport. Within the same sampled replicates of each cultivar in plots where seedlings did not exhibit symptoms, five asymptomatic

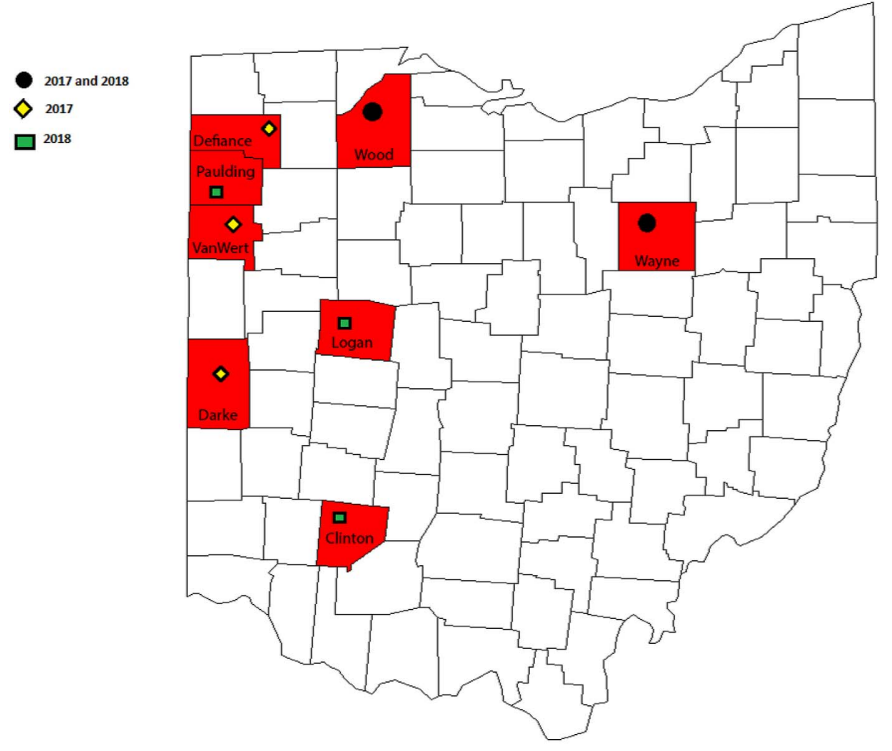

Fig. 1. Counties where fields (environments) in Ohio were selected for these studies based on reported seedling disease incidence. Field studies were in counties with a black circle in both years, yellow diamonds only in 2017, and green squares only in 2018. In two counties, Wood and Wayne, the study was located at the Northwest (NWB) and Snyder Farm (SNY), respectively, which are on Ohio State University Agricultural Research Stations. seedlings were collected. Soybean seedling samples and their associated rhizosphere soils were placed at $4{ }^{\circ} \mathrm{C}$ until processing. For processing, large clumps of soils were first removed from the seedling and discarded. Rhizospheric soil was then collected from each seedling by gently shaking the roots inside a manila envelope. The rhizospheric soil from each of the five seedlings collected from each plot was pooled into one sample and a total of $0.2 \mathrm{~g}$ was used for DNA extraction. With two environments, Defiance (DEF25dap) and Van Wert (VW25dap), the rhizospheric soil from the soybean was sampled in 2017 at the V3/V4 growth stage to evaluate the effect of rainfall and soybean growth stage on communities of Phytophthora, Phytopythium, and Pythium.

Direct isolation from seedlings and species identification. Isolation of Phytophthora, Phytopythium, and Pythium was performed as previously described by Dorrance et al. (2008). Briefly, seedling roots were gently washed under tap water to remove debris, wrapped in a paper towel, and transferred to a laminar flow hood. Roots were surface sterilized using $70 \%$ ethanol for $10 \mathrm{~s}$ followed by a 30-s rinse with sterile distilled water. Roots were blotted dry in a sterile paper towel and sections from the edge of the lesions were placed under selective media (V8-media plus pentachloronitrobenzene, iprodione, benlate, neomycin sulfate, and chloramphenicol) (Dorrance et al. 2008) and placed in an incubator at $20^{\circ} \mathrm{C}$ in 2017 and at $25^{\circ} \mathrm{C}$ in 2018 . Hyphal tips of coenocytic mycelia were transferred to potato carrot agar (PCA) plates amended with rifampicin $(100 \mu \mathrm{g} / \mathrm{ml})$. Cultures were first placed at $20^{\circ} \mathrm{C}$; if there was little to no growth after 2 days, the plate was placed at $25^{\circ} \mathrm{C}$ because $P h y$ tophthora sojae and Phytophthora sansomeana grow very slowly at the lower temperature. Pure cultures were transferred to Whatman vials with PCA for long-term storage at $15^{\circ} \mathrm{C}$.

In addition to morphological features (Van der Plaats-Niterink 1981; Waterhouse 1967), each isolate was confirmed to species, based on the full-length sequence of the ITS regions of the ribosomal gene. The DNA for each isolate was extracted as previously described by (Zelaya-Molina et al. 2011). Briefly, in total, 6 to 10 mycelia plugs from each culture were transferred to $50 \mathrm{ml}$ of V8 broth media in a $125-\mathrm{ml}$ Erlenmeyer flask and grown at room temperature for 4 days. Mycelia were collected using a Buchner funnel, macerated in liquid nitrogen with a mortar and pestle, and stored at $-20^{\circ} \mathrm{C}$. The primers ITS 1 and ITS4 (White et al. 1993) were used and the PCR master mix was prepared using the Promega GoTaq Polymerase Kit (Promega Corp, Madison, WI, U.S.A.) and consisted of $5 \mu \mathrm{l}$ of $5 \times$ colorless reaction buffer, $1.5 \mu \mathrm{l}$ of $\mathrm{MgCl}_{2}(25 \mathrm{mM}), 1 \mu \mathrm{l}$ of dNTPs $(10 \mu \mathrm{M}), 1 \mu \mathrm{l}$ of primers ITS1 $(10 \mu \mathrm{M})$ and ITS4 $(10 \mu \mathrm{M}), 0.25 \mu \mathrm{l}$ of GoTaq DNA Polymerase $(5 \mu / \mu \mathrm{l})$, and $13.25 \mu \mathrm{l}$ of ultrapure water. The PCR parameters were $95^{\circ} \mathrm{C}$ for $5 \mathrm{~min}$; followed by 30 cycles of $94^{\circ} \mathrm{C}$ for $1 \mathrm{~min}$, $53^{\circ} \mathrm{C}$ for $1 \mathrm{~min}$, and $72^{\circ} \mathrm{C}$ for $1 \mathrm{~min}$; and completed with $72^{\circ} \mathrm{C}$ for 5 min. Quality and quantity of the amplicons was measured by using the absorbance at $260 \mathrm{~nm}\left(\mathrm{~A}_{260}\right) / \mathrm{A}_{280}$ and $\mathrm{A}_{260} / \mathrm{A}_{230}$ ratios with a spectrophotometer (Nanodrop 3300; Thermo Scientific, Vernon Hills, IL, U.S.A.) and electrophoresis in a $1 \%$ (wt/vol) agarose gel with Gel Red nucleic acid stain (New England Biolabs, Ipswich, MA, U.S.A.) for $1 \mathrm{~h}$ at $90 \mathrm{~V}$.

For sequencing, amplicons were purified by mixing $2 \mu \mathrm{l}$ of ExoSAP-IT (Thermo-Fisher, Waltham, MA, U.S.A.) with $5 \mu \mathrm{l}$ of the PCR and incubated at $37^{\circ} \mathrm{C}$ for 15 min followed by $80^{\circ} \mathrm{C}$ for $15 \mathrm{~min}$. In total, $3 \mu \mathrm{l}$ of each individual primer at a concentration of 2 pmol was mixed with $6 \mu \mathrm{l}$ of purified PCR product for a final concentration of $20 \mathrm{ng} / \mu \mathrm{l}$. Purified and diluted PCR products were submitted to the Molecular and Cellular Imaging Center (MCIC) at the OARDC or the OSU James Genomic Shared Resources for Sanger sequencing using both forward and reverse primers. Sequences from both primers were quality filtered and assembled using 
Codon Code Aligner (Codon Code Corporation, Centerville, MA, U.S.A.). Sequences were then compared with voucher specimens deposited at the NCBI nucleotide nonredundant database for identification. The isolates were then classified to species based on $100 \%$ sequence match combined with the morphological features.

The ITS sequence for Pythium sp. CAL was deposited in NCBI and can be found under accession MN512275.

Pathogenicity assay. The pathogenicity of 25 isolates plus 3 isolates from the OSU soybean pathology collection and a noninoculated treatment were evaluated in a root cup assay. The isolates were selected for this assay to be representative of the diversity of species of Phytophthora, Phytopythium, and Pythium recovered from fields in 2017. The root cup assay was done in the growth chamber as previously described by Ellis et al. (2013). Briefly, spawn bags (Myco Supply, Pittsburgh, PA, U.S.A.) containing 950 $\mathrm{ml}$ of Clean Play Sand (Quikrete, Ravenna, OH, U.S.A.), $50 \mathrm{ml}$ of cornmeal (Quaker Oats Company, Chicago, IL, U.S.A.), and 250 $\mathrm{ml}$ of deionized distilled water were prepared and then autoclaved on two consecutive days. Individual sterile bags were inoculated with 8 to 10 plugs $(5 \mathrm{~mm})$ from the edge of a 5- to 7-day-old culture and sealed with a sealer-electrical impulse (Harbor Freight Tools, Calabasas, CA, U.S.A.). Bags were incubated at room temperature for 10 days and mixed manually every day. A single spawn bag was mixed with 4 liters of fine vermiculite in a 1:4 ratio, and $300 \mathrm{ml}$ of inoculum was placed on top of $100 \mathrm{ml}$ of coarse vermiculite (Perlite Vermiculite Packing Industries, Inc., North Bloomfield, OH, U.S.A.) in each 0.5-liter styrofoam cup and watered prior to planting three times over $24 \mathrm{~h}$. In total, 10 seeds of Kottman, Lorain, or Sloan were then placed on top of each individual cup and covered with an additional $100 \mathrm{ml}$ of coarse vermiculite. Cups were placed in a growth chamber at $20^{\circ} \mathrm{C}$, with $16 \mathrm{~h}$ of light and the humidity set for $20 \%$. Data were collected for plant germination and emergence at 7 dap. At 14 dap, plants were gently removed from cups and washed under tap water. Data for root rot score, root weight, shoot weight, shoot height, and final number of plants per cup were collected. Based on previous disease assays, three isolates-Miami 1-3-7 (P. ultimum var. ultimum), Brown 2-3-5 ( $P$. irregulare), and $\mathrm{OH} 25$ (Phytophthora sojae)-were used as controls in each assay (Ellis et al. 2013; Scott et al. 2019). The experiment was arranged as a randomized complete block with three replications for each cultivar and isolate combination. This experiment was conducted three times.

Soil DNA extraction. The pooled soil collected from the rhizosphere of the seedlings from each plot was ground in a blender for a homogenous sample. The PowerLyzer Power Soil Kit (Qiagen, Carlsbad, CA, U.S.A.) was used to extract the DNA following the manufacturer's protocol, with some modifications. These included PowerLyzer Homogenizer (Qiagen) at 4,000 rpm for $45 \mathrm{~s}$, a 5-min incubation period at $2^{\circ} \mathrm{C}$, and DNA was diluted with $50 \mu \mathrm{l}$ of the solution C6 from kit. Quality and quantity of DNA was measured with the 260:280 absorbance method (Nanodrop 3300; Thermo Scientific). For each sample, there were three separate DNA extractions, and these were pooled equimolar to a final concentration of $5 \mathrm{ng} / \mu \mathrm{l}$. Only the ITS1 of the RNA ribosomal genes was amplified with primers ITS6/ITS7 (Cooke and Duncan 1997; Cooke et al. 2000) using the Phusion High Fidelity DNA Polymerase (New England Biolabs) to reduce PCR errors. The reaction consisted of $5 \mu \mathrm{l}$ of $5 \times$ High Fidelity Buffer, $0.5 \mu \mathrm{l}$ of nucleotide mix $(10 \mu \mathrm{M}), 1 \mu \mathrm{l}$ of primers ITS6 and ITS7 $(2 \mu \mathrm{M})$ containing Illumina adapters, $5 \mu \mathrm{l}$ of template $(5 \mathrm{ng} / \mu \mathrm{l}), 0.2 \mu \mathrm{l}$ of Phusion Taq (1.0 U per $50 \mu \mathrm{l}$ of PCR), and $9.3 \mu \mathrm{l}$ of ultrapure water. The PCR parameters were $96^{\circ} \mathrm{C}$ for $3 \mathrm{~min}$; followed by 25 cycles of $96^{\circ} \mathrm{C}$ for $30 \mathrm{~s}, 55^{\circ} \mathrm{C}$ for $30 \mathrm{~s}$, and $72^{\circ} \mathrm{C}$ for $30 \mathrm{~s}$; and completed with $72^{\circ} \mathrm{C}$ for $5 \mathrm{~min}$. Samples were submitted to the MCIC for library preparation and sequencing.

Illumina library preparation and sequencing. There were two Mi-seq (Illumina) runs, one for environments sampled in 2017 and the second for those sampled in 2018. Amplicons of the ITS1 region generated at the laboratory were submitted to the MCIC for library preparation and sequencing. In total, $3 \mu \mathrm{l}$ of the first cleaned PCR product was used as the template for the second PCR to add the Illumina adapter sequence, which contains a unique dual combination of the Illumina Nextera indices for individual tagging of each sample. These products were then purified using the Agencourt AMPure XP beads (Beckman Coulter Life Sciences). All of the steps for library preparation and cleaning were carried out on the epMotion5075 automated liquid handler (Eppendorf, Hauppauge, NY, U.S.A.). The amplicon libraries were quantified and pooled at equimolar ratios before sequencing. The final pool was purified using the Pippin Prep size-selection system (Sage Science) to discard the presence of any primer dimers. The Mi-Seq sequencing platform (Illumina) was used for amplicon sequencing

TABLE 1

Species listed within each Pythium clade have identical sequences between internal transcribed spacer (ITS)6 and ITS7 based on phylogenetic analysis of 959 positions of the fulllength ITS sequence from 113 voucher accessions using MEGA7

\begin{tabular}{|c|c|}
\hline Pythium clade $^{a}$ & Species $^{b}$ \\
\hline \multirow[t]{6}{*}{ Clade $\mathrm{A}$} & Pythium adhaerens \\
\hline & P. chondricola \\
\hline & P. porphyrae \\
\hline & P. aristosporum \\
\hline & P. catenulatum \\
\hline & P. folliculosum* \\
\hline \multirow[t]{3}{*}{ Clade B1 } & P. myriotylum \\
\hline & P. torulosum \\
\hline & P. zingiberis \\
\hline \multirow[t]{8}{*}{ Clade B2 } & P. capillosum \\
\hline & P. coloratum \\
\hline & P. diclinum \\
\hline & P. dissotocum \\
\hline & $P$. flevoense \\
\hline & P. lutarium \\
\hline & P. marinum \\
\hline & P. pachycaule* \\
\hline \multirow[t]{3}{*}{ Clade D } & P. amasculinum \\
\hline & P. aff. hydnosporum* \\
\hline & P. oligandrum \\
\hline \multirow[t]{2}{*}{ Clade E1 } & P. acrogynum* \\
\hline & P. hypogynum \\
\hline \multirow[t]{3}{*}{ Clade I } & P. ultimum* \\
\hline & P. ultimum var. sporangiiferum \\
\hline & P. ultimum var. ultimum \\
\hline
\end{tabular}


at a final concentration of $14.3 \mathrm{pM}$. Amplicon libraries were spiked with PhiX libraries to allow a more heterogeneous sample and reduce error in the run introduced by the high levels of similar nucleotides among oomycetes. The run was clustered to a density of $905 \mathrm{k} / \mathrm{mm}^{2}$ and the libraries were sequenced using a $300 \mathrm{PE} \mathrm{Mi-}$ Seq sequencing kit with the standard Illumina sequencing primers. Image analysis, base calling, and data quality assessment were performed on the Mi-seq platform.

Amplicon sequencing data processing. Data quality was first assessed using the FastQC and MultiQC software (Wingett and Andrews 2018). Removal of Illumina barcodes and merging of the short paired-end reads was performed using the BBMerge command in BBTools suit. Prior to data processing using the USEARCH pipeline (Edgar 2010), the two Mi-seq runs were pooled together. Quality filtering was done using a threshold of $1 \%$ expected errors (Edgar and Flyvbjerg 2015). The ITS1 region was trimmed from the sequences using the ITSx (Bengtsson-Palme et al. 2013) software, version 1.0.11. This was followed by dereplication to find set of unique sequences and remove duplicated short reads from initial data set. Dereplicated short reads were first clustered into operational taxonomic unit (OTU) clustering using a de novo approach at $97 \%$ similarity level using the UPARSE distance-based greedy-approach algorithm (Edgar 2013). Finally, taxonomy was assigned to OTUs using the -sintax command with $100 \%$ similarity level using a custom-made database. The database was the same as used in an earlier study (Navarro et al. in press), and this was composed of full ITS sequence accessions retrieved from Hyde et al. (2014), Lévesque and de Cock (2004), and Robideau et al. (2011) in addition to internal sequences generated from the laboratory during previous surveys. The database was trimmed to only the ITS1 region using the ITSx (Bengtsson-Palme et al. 2013) software, version 1.0.11. Further filtering steps and data analysis were carried out using the phyloseq (McMurdie and Holmes 2013), MetagenomeSeq (Paulson et al. 2013), and Vegan (Oksanen et al. 2019) packages in $\mathrm{R}$, version 3.5.0.

The microbiome data for this paper was deposited to the Sequence Read Archive under project number is PRJNA590039.

Statistical analysis. Early plant population and yield data were first analyzed for all environments. Assumptions were tested using the Levene's test for homogeneity of variance and Shapiro-Wilk for normality in SAS (SAS version 9.4; SAS Institute, Cary, NC, U.S.A.). An analysis of variance (ANOVA) to test the main effect of environment, cultivar, and replicate as well as the interactions of these three factors was run using PROC MIXED. Significant $(P$ value $<0.05)$ interactions of environment-cultivar dictated that ANOVAs were run independently for each environment to test effects of cultivar.

For the amplicon sequencing data, OTU tables were first subset for species of Phytophthora, Phytopythium, and Pythium. In this data set, only three, seven, eight, three, two and two Pythium spp. within the clades A, B1, B2, D, E1, and I, respectively, shared identical sequences when using primers ITS6 and ITS7 (Table 1) (Lévesque and de Cock 2004; Redekar et al. 2019; Robideau et al. 2011). For species with identical sequences, taxonomical identification for the OTU was to one species. The Shannon's diversity index was calculated using the diversity function in the vegan package (Oksanen et al. 2019) in R ( $\mathrm{R}$ Core Team 2018) to assess species richness and evenness from nonnormalized data. Due to violation of normality assumptions, comparison of the mean diversity index between environments was done using the Kruskal-Wallis test (Kruskal and Wallis 1952) followed by a posthoc analysis using the Dunn test for multiple comparison of environments. To test the main effects of environment and cultivar on the community composition of oomycetes, OTU sequence counts were normalized using the

TABLE 2

Summary of total precipitation and average temperature for each environment in Ohio where soybean seedlings were sampled and the total number of isolates of Phytophthora, Phytopythium, and Pythium recovered from cultivars Kottman (K), Lorain (L), and Sloan (S) with different levels and types of resistance

\begin{tabular}{|c|c|c|c|c|c|c|c|c|c|}
\hline \multirow[b]{2}{*}{ Environment $^{\mathrm{a}}$} & \multicolumn{4}{|c|}{ Water $(\mathrm{cm})^{\mathrm{b}}$} & \multirow[b]{2}{*}{$\mathrm{T}\left({ }^{\circ} \mathrm{C}\right)^{\mathrm{d}}$} & \multicolumn{4}{|c|}{ Number of isolates recovered ${ }^{e}$} \\
\hline & $\mathrm{R} 14$ & Irrig & Total- $14^{c}$ & $\mathrm{R} 25$ & & E & $\mathrm{K}$ & $\mathrm{L}$ & S \\
\hline DAK17 & 2.4 & - & 2.4 & - & 15 & 3 & 0 & 3 & 0 \\
\hline VW17 & 3.9 & - & $3.9^{*}$ & - & 14 & 18 & 1 & 5 & 12 \\
\hline VW25dap & - & - & - & 10.2 & - & - & - & - & - \\
\hline DEF25dap & - & - & - & 8.5 & - & - & - & - & - \\
\hline NWB17 & 3.8 & 6.1 & 9.3 & - & 15 & 74 & 17 & 20 & 37 \\
\hline SNY17 & 5.2 & - & 5.2 & - & 14 & 58 & 12 & 14 & 32 \\
\hline PAL18 & 2.8 & - & 2.8 & - & 19 & 15 & 3 & 4 & 8 \\
\hline NWB18 & 2.2 & 3.6 & 5.8 & - & 16 & 45 & 10 & 12 & 23 \\
\hline Total & - & - & - & - & - & 277 & 61 & 69 & 147 \\
\hline \multicolumn{10}{|c|}{$\begin{array}{l}\text { abbreviations indicate county and year. } \\
\text { b R14 and R25 = rain at } 14 \text { and } 25 \text { days after planting, respectively; Irrig = irrigation; and Total-14 = R14 plus irrigation. } \\
\text { c An asterisk }(*) \text { indicates that precipitation occurred } 3 \text { days before sampling. } \\
\text { d Average air temperature. } \\
\text { e Total number of isolates recovered by environment }(\mathrm{E}) \text { or cultivar. }\end{array}$} \\
\hline
\end{tabular}


cumulative-sum scaling method in the package Metagenomeseq in $\mathrm{R}$ (Paulson et al. 2013). Data were then relativized to convert each OTU to a percentage of the total OTUs per sample. A Bray-Curtis dissimilarity matrix was then calculated from relativized data and subject to nonmetric multidimensional scaling (NMDS) ordination plots using the function metaMDS. Based on the species assigned to each OTU, a permutation analysis of variance (PERMANOVA) (Anderson 2001) was conducted with the adonis function in $\mathrm{R}$ to assess significance of environment, cultivar, and the environmentcultivar interaction in the community composition of Phytophthora, Phytopythium, and Pythium (Anderson 2001). To understand the oomycete species indicative of each environment, the package indicspecies (De Cáceres and Legendre 2009) was used. This allowed us to determine which oomycete species were indicator species in each environment.

\section{RESULTS}

Environmental conditions. The amount of rainfall and mean air temperature from planting to sampling date for each environment are summarized in Table 2. Rainfall amounts were similar overall in 2017 and 2018 and ranged from 22.6 to $74.9 \mathrm{~mm}$. For two environments, VW17 and DEF17, rainfall occurred 3 to 5 days prior to sampling, and this may have limited seedling disease development (Table 2). For SNY18, conditions were conducive for disease based on rainfall; however, the slope of the field allowed for drainage, thus limiting the amount of damping-off that occurred. Flooding conditions occurred at CLN18 following the first stand counts, where stand and yield losses reached $100 \%$ in many of the plots and the surviving plots were discarded. The NWB17 and NWB18 fields were irrigated to field capacity (Supplementary Fig. $\mathrm{S} 1$ ) and these two environments had the greatest number of isolates recovered across both years.

Early plant population and yields. There was a highly significant effect $(P<0.0001)$ of environment and cultivar for early plant population and yield (Supplementary Table S1) and the interaction between environment and cultivar was highly significant for early plant population $(P<0.0001)$ and yield $(P=0.0090)$. Due to significance of the interaction term, the environments were analyzed individually. Based on ANOVA for the environments separately, there was a significant difference $(P<0.01)$ among the cultivars in 6 of 11 and 5 of 10 environments for early plant population and yield, respectively. Due to heavy flooding injury, the yield data for CLN18 was not collected. Among the six environments, the cultivar Kottman (Rpslk and $3 a$ plus moderate resistance to Phytophthora sojae) had significantly higher early plant populations compared with Sloan (moderately susceptible) in five environments (CLN17, DEF17, NWB17, CLN18, and PAL18). Similarly, the cultivar Lorain (Rpslc plus partial resistance to Phytophthora sojae and moderate resistance to Pythium ultimum var. ultimum and $P$. ultimum var. sporangiiferum) had significantly higher stands compared with Sloan, but only in two environments (CLN17 and NWB17). In terms of yield, Kottman had significantly higher yields in five environments (DAK17, NWB17, NWB18, PAL18, and SNY18). Yields for Lorain were similar to Kottman, except for environments SNY18, where yields were not significantly different from Sloan (Fig. 2), and NWB17, where both early plant population and yield were significantly higher than both Kottman and Sloan. Based on lower plant population per hectare for the susceptible cultivar Sloan compared with other cultivars, six environments (CLN17, DEF17, NWB17, CLN18, PAL18, and SNY18) had the highest disease pressure. It is noteworthy that two environments were marginally significant for early plant population PAL $(P=$ $0.0666)$ and NWB18 $(P=0.0755)$.
Direct isolation. In total, 277 isolates representing 2, 4, and 20 species of Phytophthora, Phytopythium, and Pythium, respectively, were recovered from symptomatic seedlings across the 11 environments sampled at seedling stage. Each of the environments had different species composition of pathogens recovered from the soybean seedlings (Fig. 3; Supplementary Table S2). Overall, the species of Pythium isolated from soybean seedlings at a high frequency were $P$. oopapillum, $P$. sylvaticum, $P$. ultimum var. ultimum, $P$. dissotocum, $P$. torulosum, and $P$. inflatum with 51, 32, 30, 18,13 , and 12 total isolates, respectively. In addition, from all of the isolates recovered, 147 were retrieved from the susceptible cultivar Sloan, whereas 69 and 61 isolates were recovered from Kottman and Lorain, respectively (Table 2; Fig. 3).

There were 10 and 26 isolates of Phytophthora sojae recovered from Lorain and Sloan, respectively, whereas there were 5 and 10 of Phytophthora sansomeana from the same cultivars. Kottman had the fewest isolates, with 1 and 5 of $P$. sojae and $P$. sansomeana; respectively (Fig. 3). P. sojae and P. sansomeana were isolated from seedlings from seven and five environments. Among the four species of Phytopythium, Phytopythium mercuriales was recovered from NWB18, located in northern Ohio, while Phytopythium vexans was recovered only from CLN17, located in southern Ohio (Fig. 3). Interestingly, a high proportion of isolates
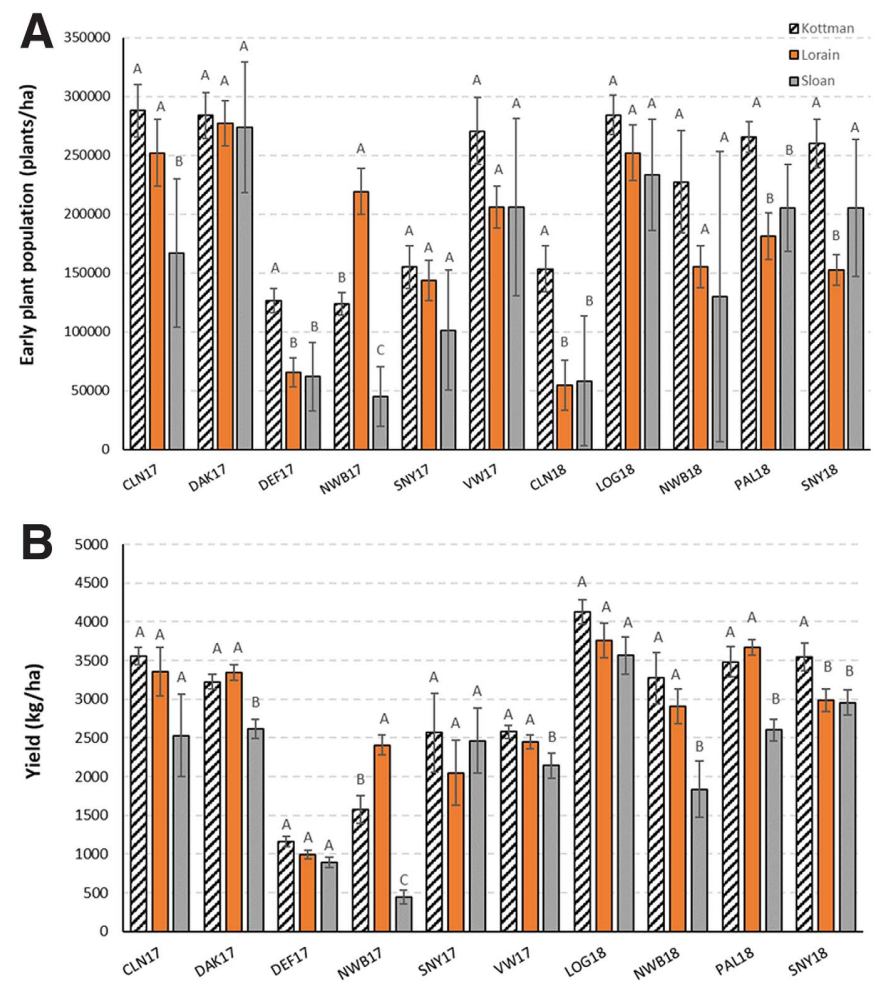

Fig. 2. Field assessment of the soybean cultivars Kottman, Lorain, and Sloan with different levels and types of resistance toward Phytophthora sojae and species of Pythium across 11 environments in Ohio. A, Early plant population data were collected at V1 to V3 soybean growth stages whereas $\mathbf{B}$, yield data were collected at soybean growth stage R8. Analysis of variance showed significant differences for cultivar, environment, and the cultivar-environment interaction $(P$ values $<0.0001)$. Means followed by the same letter are not significantly different based on the Fisher's protected least significant difference test within each environment. Bars represent standard deviation of the mean, with $n=8$ plots per cultivar per environment sampled. 
(33 of 51) were identified as Pythium oopapillum from NWB17 (Fig. 3).

Pathogenicity of isolates recovered from the field. Twentyfive of the isolates recovered from the environments sampled in 2017 along with three control isolates and a noninoculated were tested for pathogenicity toward the soybean cultivars Kottman, Lorain, and Sloan. All of the roots had symptoms of root rot following inoculation, ranging from minor browning to total seedling death. The root weight following inoculation was used to compare pathogenicity among the isolates (Fig. 4). There was a highly significant difference for seedling root weight among isolates $(P<$ $0.001)$, a marginally significant effect for cultivar $(P=0.06)$, and no significance for the interaction between isolate and cultivar $(P>$ 0.05). The check isolate, $P$. ultimum (Miami), had significantly lower root weight compared with the noninoculated control in the three cultivars, whereas the check isolate $P$. irregulare (Brown 2-3-5) had lower root weights in Kottman and Lorain and isolate Phytophthora sojae (OH25) had lower root weights in Sloan and Lorain (Fig. 4). In addition, seedlings inoculated with Pythium perplexum had significantly lower root weight across all cultivars. Inoculations with isolates of Phytophthora sansomeana, Phytophthora sojae, Pythium sylvaticum, P. ultimum var. ultimum, and $P$. attrantheridium resulted in significantly lower root weight for Lorain. Overall, five, eight, and four isolates had significantly lower root weight compared with the noninoculated control for Kottman, Lorain, and Sloan, respectively (Fig. 4).

Diversity and community composition of Phytophthora, Phytopythium, and Pythium based on amplicon sequencing. Due to violation of normality assumptions, data for the Shannon's diversity index was analyzed using the nonparametric KruskalWallis test (Kruskal and Wallis 1952). Environment had a highly significant effect $(P<0.0001)$ on the diversity of Phytophthora, Phytopythium, and Pythium spp. but cultivars $(P=0.4564)$ and the cultivar-environment interaction $(P=0.0963)$ were not significantly different. The environments DAK17, VW17, LOG18, and VW25dap had the lowest diversity, with indices of 1.3, 1.8, 1.9, and 2.0, respectively (Supplementary Table S3). The VW25dap is the same environment as VW17 and diversity values were not significantly different from each other $(P=0.50)$. Interestingly, the mean Shannon's diversity index was significantly different between DEF17 and DEF25dap $(P<0.001)$ environments sampled at the V1 to V3 and V3 to V5 growth stages. Environments NWB17 and NWB18 were not significantly different $(P=0.41)$, showing how diversity was consistent at this location (Fig. 5; Supplementary Table S3).

To test whether the community composition of Phytophthora, Phytopythium, and Pythium spp. was different among environments and cultivars, PERMANOVA was conducted on the OTU counts. There was a significant effect for both environment $(P<0.001$; $\left.R^{2}=0.48\right)$ and cultivar $\left(P<0.001 ; R^{2}=0.01\right)$ on community composition. Distinct communities were observed in each environment and these were different even at the two sampling times for environments DEF17, DEF25dap, and VW17, VW25dap (Fig. 6). However, the environments which were irrigated to field capacity (NWB17 and NWB18) had very similar communities but differed from all other environments (Fig. 6). The effect of cultivar could only explain $1 \%$ of the total variance within each environment. To test whether cultivar influenced the abundance of specific genera, the data were subset to the genus level. Based on ANOVA, the relativized abundance of Phytophthora spp. was significantly $(P<$ 0.001 ) influenced by soybean cultivar but cultivar had no effect on the abundance of Phytopythium and Pythium spp.

Effect of environment on the species abundance of Phytophthora, Phytopythium, and Pythium. The abundance of Phytophthora, Phytopythium, and Pythium spp. was different among environments. At a threshold of 100 counts, at least 31 OTUs of species of Pythium, 2 species of Phytophthora, and 1 species of Phytopythium were detected in one or more of the 11 environments as well as the 2 environments that were sampled at 25 dap (Fig. 7, Supplementary Table S2). Because OTUs were detected that match species within Pythium clades B1, B2, D, E1, and I, there may, in fact, be more species present. Overall,

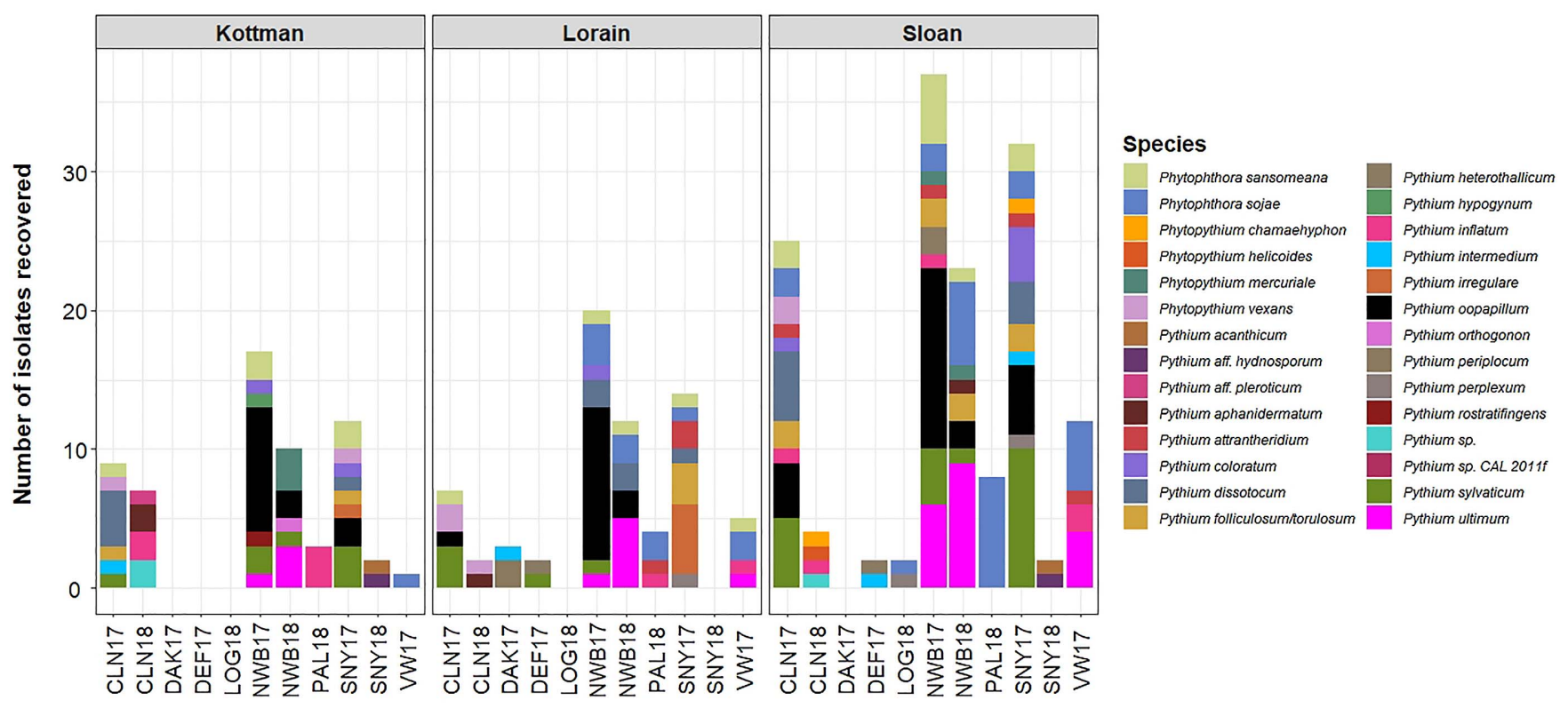

Fig. 3. Number of isolates of Phytophthora, Phytopythium, and Pythium recovered from soybean seedlings of the cultivars Kottman, Lorain, and Sloan with different levels and types of resistance using a direct isolation technique. Seedlings were collected at V1 to V3 growth stages across the 11 environments in Ohio during 2017 and 2018. Cultures were incubated at $20^{\circ} \mathrm{C}$, and species were identified by amplifying and sequencing of the ribosomal RNA gene with primers internal transcribed spacer (ITS)1 and ITS4. 
environments DAK17 and DEF25dap had the lowest number of species, with only five and six species of Pythium present, respectively (Fig. 7). Some Pythium spp. were found in all of the environments, including $P$. attrantheridium, $P$. heterothallicum, and $P$. sylvaticum, all known pathogens of soybean. The undescribed Pythium sp. CAL2011f was highly abundant across all cultivars and environments, except for DEF17. Also, P. monospermum was present in nine environments, except for NWB17 and NWB18. Similarly, $P$. minus was present in 10 environments, except for DEF25dap. Based on the relativized abundance in the NMDS analysis, environments NWB17 and NWB18 did not differ in community composition; however, there were a few species that differed. For example, OTUs belonging to the species $P$. nodosum, $P$. oopapillum, and $P$. ultimum were only observed at NWB17, whereas $P$. acanthicum, $P$. orthogonon, and Pythium sp. CAL2011f were only at NWB18. The two environments sampled at two different growth stages had very distinct communities at each sampling time. For example, in the VW17 early growth stage sample, five species were found and the community was characterized by Phytophthora sojae, Pythium acanthicum, and P. periilum whereas, at VW25dap, the community was characterized by the presence of three species, including Phytophthora sansomeana, Pythium acrogynum, and Pythium sp. CAL2011f. For DEF17, OTUs representing a total of 16 species of Pythium were found whereas, at the second sampling date (DEF25dap), only six species of Pythium were found.
Effect of cultivar on the species abundance of Phytophthora, Phytopythium, and Pythium spp. The abundance of Phytopythium and Pythium spp. was influenced by environment while Phytophthora spp. abundance was influenced by both environment and cultivar (Table 2). At the threshold of detection, Phytophthora sojae and Phytophthora sansomeana were not present in environments DAK17, CLN17, DEF17, and DEF25dap when the seedlings were sampled. However, late-season stem rot caused by Phytophthora sojae was widely distributed in all three environments. For CLN18, Phytophthora sansomeana was $84 \%$ more abundant than Phytophthora sojae. More importantly, the abundance of Phytophthora sojae in the rhizosphere was significantly affected by cultivars. For example, the abundance of Phytophthora sojae associated with Sloan was greater than from resistant Kottman (ANOVA; $P=0.001$ ) across all environments (Fig. 7), whereas the abundance of Phytophthora sansomeana was not affected by cultivar. For Pythium spp., Pythium pachycaule (representing Pythium clade B2) (Table 1) was the only species for which abundance was significantly $(P=0.013)$ affected by cultivar, with greater abundance associated with Sloan compared with Kottman (Table 3).

Indicator species associated with 11 environments in Ohio. Based on OTUs of Pythium, Phytopythium, and Phytophthora, there were 50 species that were significant indicators of the environments selected (Table 4). Based on specificity, fidelity, and the indicator values from the indicator species analysis, environmental conditions

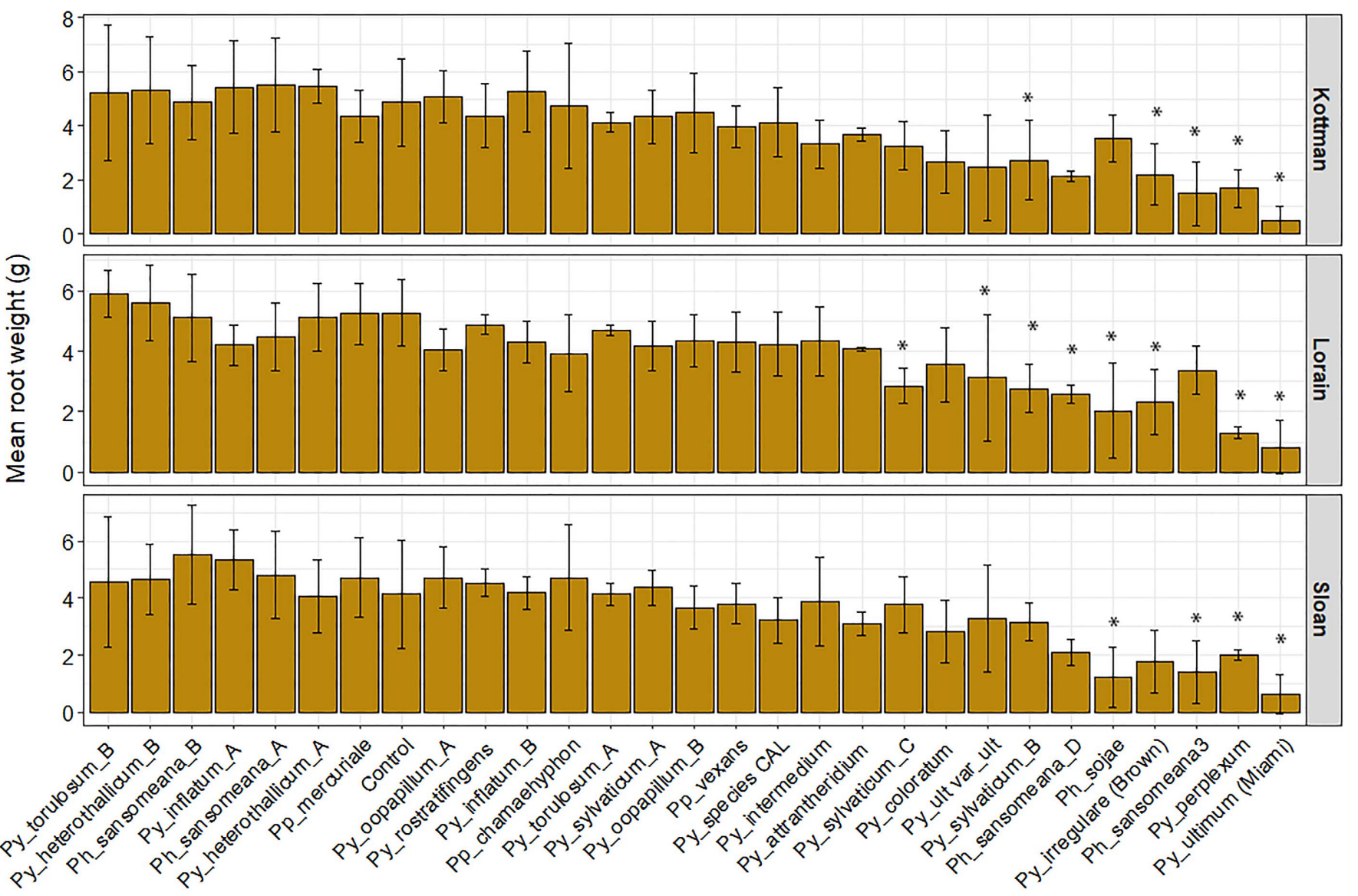

Fig. 4. Mean root weight from pathogenicity assays of Phytophthora, Phytopythium, and Pythium isolates recovered from soybean seedlings in 2017. Species with more than one isolate are represented with an A or B. Control = noninoculated and Phytophthora sojae OH25, Pythium irregulare (Brown), and Pythium ultimum (Miami) were controls from the soybean pathology collection. Soybean cultivars Kottman, Lorain, and Sloan, with different levels and types of resistance $(R p s 1 k+R p s 3 a$ and high partial resistance, Rps1c and high partial resistance, and moderately susceptible, respectively), were tested using the root cup assay method. An asterisk $(*)$ represents a significant reduction in root weight $(P<0.05)$ when compared with the noninoculated control. Bars represent standard deviation of the means. 


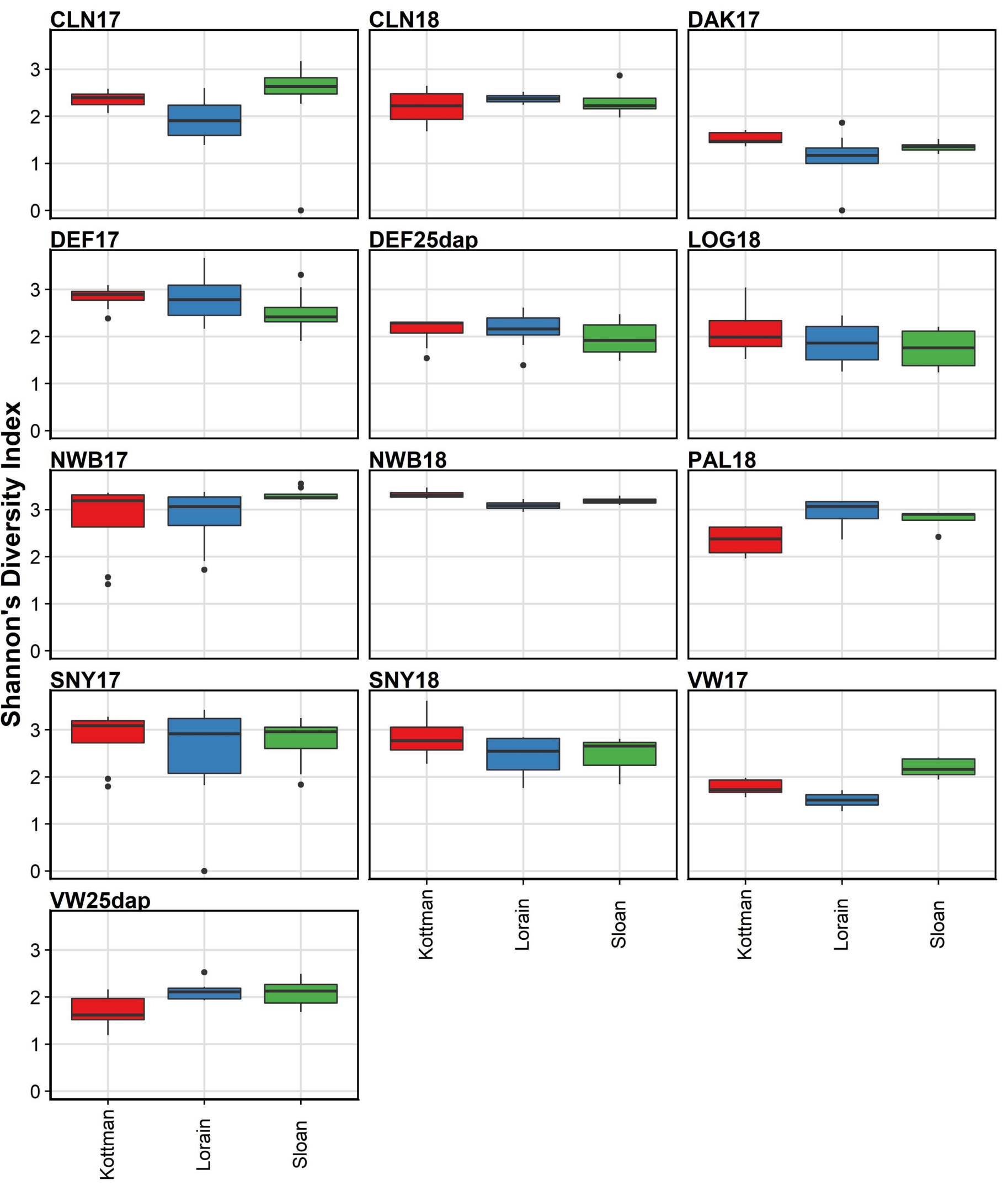

Fig. 5. Shannon's diversity index for the species of Phytophthora, Phytopythium, and Pythium detected in the rhizosphere of the cultivars Kottman, Lorain, and Sloan, with different levels and types of resistance, across 11 field environments and 2 fields that were sampled at a later time point in Ohio. Shannon's diversity index was calculated using the VEGAN package in R from sequence counts. Environments DEF25dap and VW25dap were sampled at growth stages V3 to V5, whereas the other 11 at soybean growth stages V1 to V2. 
played an important role in in the abundance, development, and competition of oomycete species in these fields in Ohio. Indicator analyses suggest that oomycete community composition was driven more by fidelity (lack of occurrence in other environments) than by specificity (occurrence exclusively within a environment), because 32 of the 50 identified species had larger fidelity values relative to specificity values (Table 4). The notable exception to this was in CLN18 and DEF17, which both had more species with higher specificity values than fidelity values.

Based on PERMANOVA analysis, community compositions in environments NWB17 and NWB18 were not significantly different from each other. However, the species indicators for these two environments were not the same (Table 4). For example, the species Pythium longandrum, $P$. nodosum, $P$. acrogynum, Phytopythium mercuriales, and Phytophthora sansomeana were significant indicator species in NWB17, while Pythium ultimum, P. aphanidermatum, Phytopythium vexans, Pythium orthogonon, Phytophthora sojae, and Pythium nunn were significant indicators of NWB18. For the remaining environments, there were one to six indicator species with very few similarities (Table 4). Additionally, when environments sampled in the same year at two different time points were compared, there were different indicators species observed. The species Pythium chondricola was an indicator of the environment DEF17 whereas, in the same environment sampled later (DEF25dap), the unclassified Pythium sp. CAL2011f was one of the five indicator species. Only one indicator species was observed for environments VW25dap and CLN17.

\section{DISCUSSION}

The diversity of species of Phytophthora, Phytopythium, and Pythium recovered from soybean in this and previous surveys from regions where environmental conditions and soil types differ from one another demonstrates the adaptability and diversity of this group of oomycetes to many different environments (Dorrance et al. 2004; Broders et al. 2007. 2009; Matthiesen et al. 2016; Navarro et al. in press; Radmer et al. 2017; Rojas et al. 2017a; Serrano and Robertson 2018; Zitnick-Anderson and Nelson 2015). This study characterized the community composition of Phytophthora, Phytopythium, and Pythium spp. from three soybean cultivars with

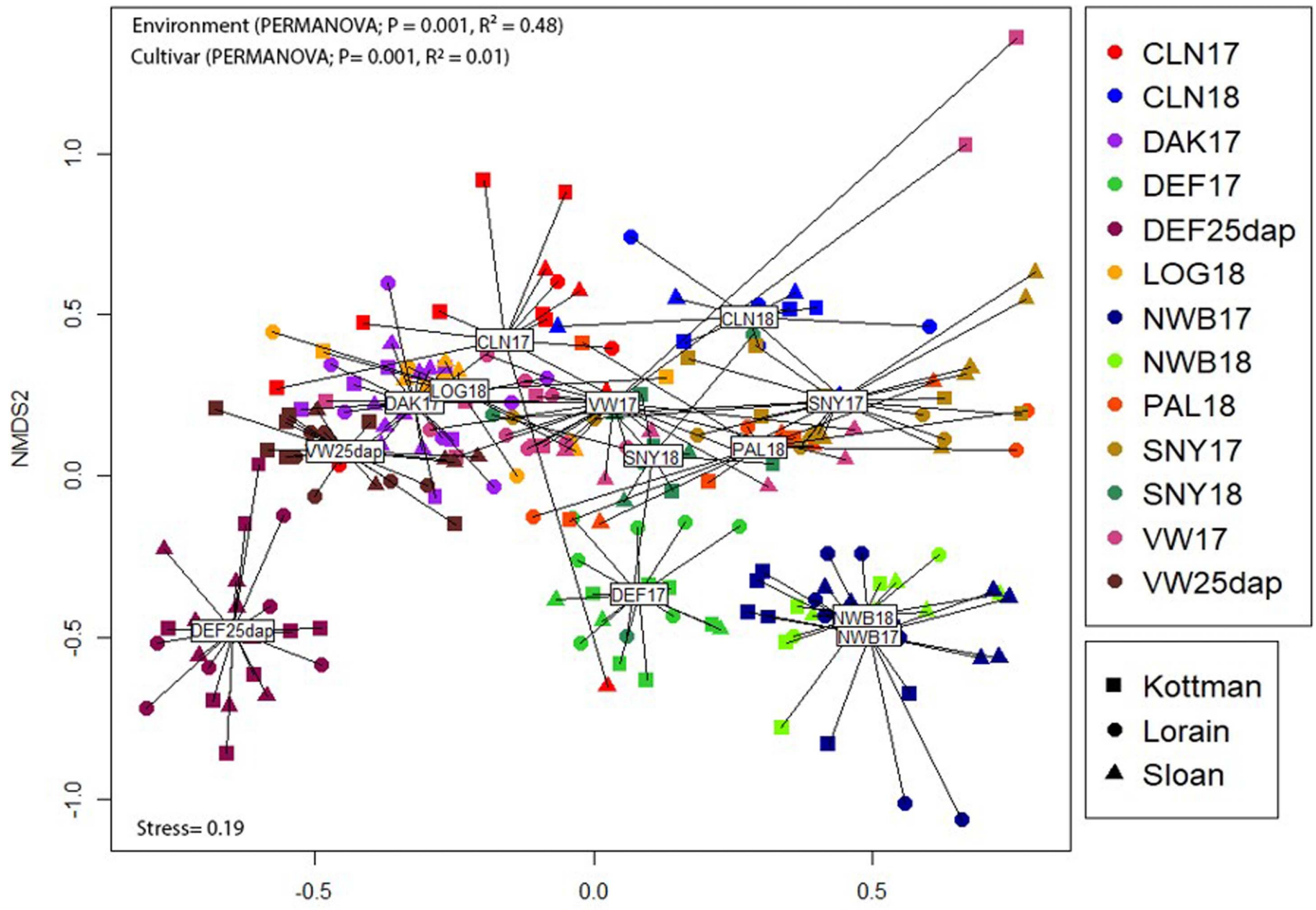

NMDS1

Fig. 6. Nonmetric multidimensional scaling (NMDS) plots using Bray-Curtis dissimilarity of Phytophthora, Phytopythium, and Pythium community data retrieved from the rhizosphere of three soybean cultivars with different levels and types of resistance across 11 field environments were sampled at in Ohio. Colors represent environments sampled and shapes represent cultivars. Environments DEF25dap and VW25dap were sampled at growth stages V3 to V5, whereas the other environments were sampled at V1 to V2. Permutation analysis (PERMANOVA) showed environments significantly contributing to the community composition. Lines are depicting convex hulls enclosing all samples pertaining to the same environment. 
different types and combinations of resistance across 11 high-disease environments and 2 environments sampled a second time at 25 dap. It should be noted, as others have in these types of studies (Navarro et al. in press; Redekar et al. 2019), that an amplicon sequencing approach can underestimate the total number of species, because the region that is amplified is identical for a few species in some of the clades (Lévesque and de Cock 2004; Robideau et al. 2011). Even with this limitation, more than 30 OTUs were detected in this amplicon sequencing approach, and those were quite different across environments.

Environment (soil plus environmental factors) can significantly affect microbial communities in the rhizosphere. For example, the microbial communities associated with the rhizosphere of strawberry (Fragaria ananassa), oilseed rape (Brassica napus), and potato (Solanum tuberosum) were affected by the seasonal changes that occurred during a 2-year sampling period (Smalla et al. 2001). Similarly, Phytophthora, Phytopythium, and Pythium spp. may be affected by environmental changes, requiring optimal temperatures and high moisture levels for growth and pathogenicity based on laboratory and field experiments of several species of oomycetes (Erwin and Ribeiro 1996; Martin and Loper 1999; Matthiesen et al. 2016; Radmer et al. 2017; Schroeder et al. 2013; Serrano and Robertson 2018). Latitude, longitude, and precipitation were among the most significant factors driving overall abundance and community composition in a survey of soybean seedlings conducted across the Midwest (Rojas et al. 2017b). In addition, Navarro et al. (in press) reported that communities of Phytophthora, Phytopythium, and Pythium spp. were different between soil incubated at $15^{\circ} \mathrm{C}$ compared with $25^{\circ} \mathrm{C}$ using a soil-bating technique.

Among the species of Phytophthora, Phytopythium, and Pythium detected in this study via amplicon sequencing and direct isolation, several had been previously reported in Ohio. For example, Pythium sylvaticum and P. oopapillum were found across all environments and cultivars and are also among the most recovered species across previous surveys conducted in Ohio (Broders et al. 2007, 2009; Dorrance et al. 2016) (unpublished data). In addition, the distribution of these species suggests that they may be core species associated with soybean. Other species such as
$P$. attrantheridium and $P$. heterothallicum were also highly abundant based on the number of OTUs but few isolates were recovered from seedlings. This low recovery of isolates may have been due to the different soil temperatures among the environments at the time of planting, compared with incubation temperatures during isolation. For instance, some studies have used temperatures of 23 to $25^{\circ} \mathrm{C}$ for the recovery of isolates of $P$. attrantheridium and when testing for pathogenicity against soybean (Broders et al. 2007; Radmer et al. 2017; Rojas et al. 2017a; Zitnick-Anderson and Nelson 2015). In this study, $20^{\circ} \mathrm{C}$ was used for root tissue incubation during isolation, which may have reduced the ability to recover this species because warmer temperatures appear to be optimal for growth and pathogenicity (Radmer et al. 2017; Rojas et al. 2017a; Zitnick-Anderson and Nelson 2015). P. ultimum was readily detected by both amplicon sequencing and direct isolation in this study. Both $P$. ultimum var. ultimum and P. ultimum var. sporangiiferum have been recovered from many soybean-producing regions and have been used in many germplasm screenings. $P$. ultimum is highly pathogenic toward soybean and its detection through this and many other surveys suggests that this species is also a core species. P. monospermum was also highly abundant across all environments but has not been reported as a pathogen of soybean or corn. This species was originally isolated from dead insects in many parts of the world (van der Plaats-Niterink 1981) as well as reported to parasitize nonstylet-bearing nematodes (Tzean and Estey 1981). The saprophytic and parasitic lifestyles of $P$. monospermum have been hypothesized to be part a survival mechanism when the host is not present (Tzean and Estey 1981). Interestingly, this species was also detected from soils of fields with a soybean-corn rotation scheme in Pennsylvania with amplicon sequencing (Coffua et al. 2016) and isolated from soybean seedlings in the North-Central region of the United States (Rojas et al. 2017a). Another important aspect of amplicon sequencing is the detection of low-abundance taxa and the detection of taxa that cannot be isolated when using traditional isolation methods alone. In this study, $P$. periilum was detected in some fields with amplicon sequencing but not isolated directly from seedlings and was also an indicator species for PAL18. This species was previously isolated from soybean

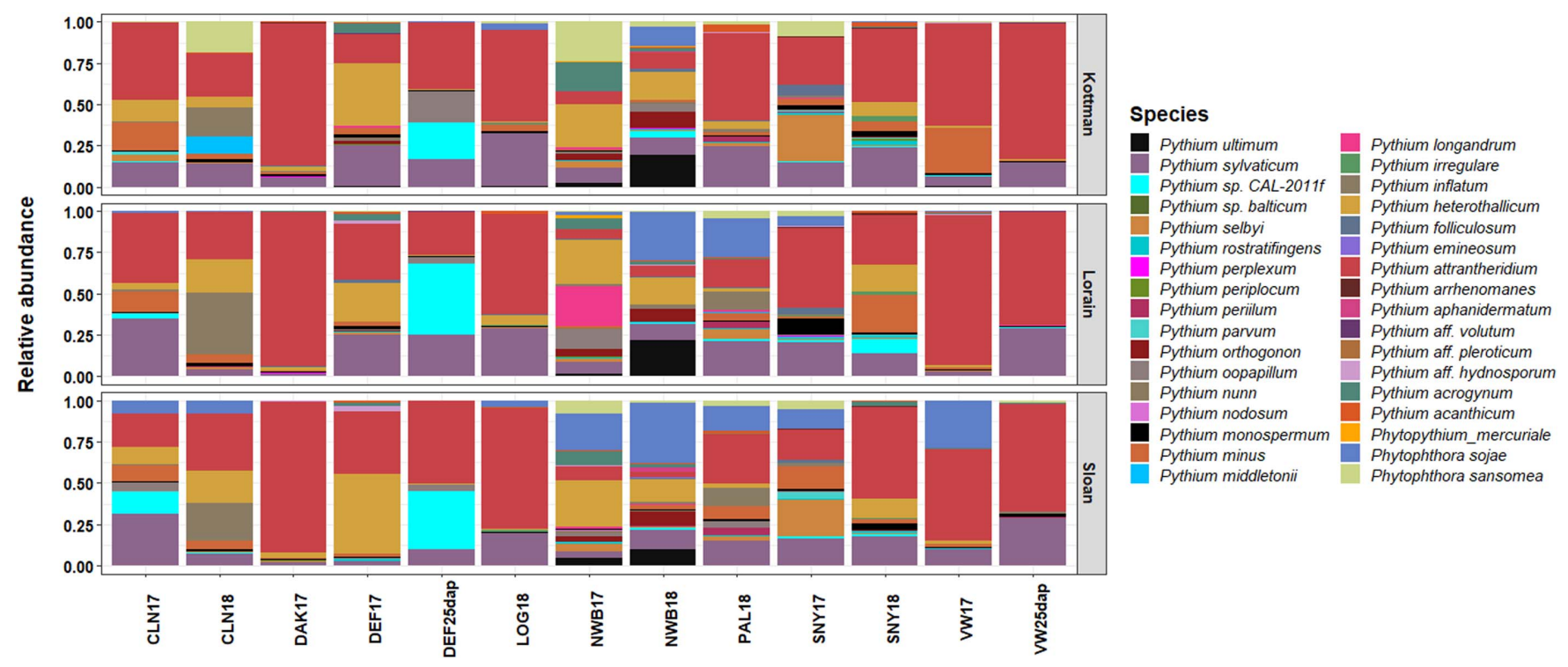

Fig. 7. Relative abundance based on cumulative sum scaling normalized counts $(n=8)$ of the species of Phytophthora, Phytopythium, and Pythium detected in the rhizosphere of the cultivars Kottman, Lorain, and Sloan with different levels and types of resistance, across 11 field environments in Ohio. 
seedlings in North Dakota, where it was first reported as a pathogen of soybean in the United States (Zitnick-Anderson and Nelson 2015). It was isolated from soybean seedlings plated into PARB+B media incubated at $23^{\circ} \mathrm{C}$ which was different from the protocol

TABLE 3

Analysis of variance significance $P$ values of the effects of environment and cultivar for the abundance of species of Phytophthora, Phytopythium, and Pythium using an amplicon sequencing approach ${ }^{\mathrm{a}}$

\begin{tabular}{|c|c|c|c|}
\hline Species & $\begin{array}{l}\text { Pythium } \\
\text { clade }^{\mathrm{b}}\end{array}$ & Environment & Cultivar \\
\hline Phytophthora sojae & & 0.002 & 0.016 \\
\hline Phytophthora sansomeana & & 0.314 & 0.124 \\
\hline Phytopythium chamaehyphon & $\mathrm{K}$ & 0.376 & 0.242 \\
\hline Phytopythium helicoides & $\mathrm{K}$ & 0.405 & 0.385 \\
\hline Phytopythium vexans & $\mathrm{K}$ & 0.010 & 0.461 \\
\hline Phytopythium mercuriale & $\mathrm{K}$ & 0.231 & 0.436 \\
\hline Pythium acanthicum & $\mathrm{D}$ & 0.012 & 0.523 \\
\hline Pythium acrogynum & E1 & $<0.001$ & 0.382 \\
\hline Pythium aff. hydnosporum & $\bar{D}$ & 0.001 & 0.752 \\
\hline Pythium aff. pleroticum & E2 & $<0.001$ & 0.694 \\
\hline Pythium aff. volutum & B1 & $<0.001$ & 0.383 \\
\hline Pythium aphanidermatum & $A$ & 0.123 & 0.409 \\
\hline Pythium arrhenomanes & B1 & $<0.001$ & 0.407 \\
\hline Pythium attrantheridium & $F$ & $<0.001$ & 0.720 \\
\hline Pythium chondricola & A & $<0.001$ & 0.346 \\
\hline Pythium conidiophorum & B1 & $<0.001$ & 0.732 \\
\hline Pythium folliculosum & B1 & $<0.003$ & 0.287 \\
\hline Pythium heterothallicum & I & $<0.001$ & 0.740 \\
\hline Pythium inflatum & B1 & $<0.001$ & 0.117 \\
\hline Pythium irregulare & $\mathrm{F}$ & $<0.001$ & 0.470 \\
\hline Pythium longandrum & E1 & 0.268 & 0.382 \\
\hline Pythium middletonii & E2 & 0.444 & 0.428 \\
\hline Pythium minus & E2 & 0.417 & 0.820 \\
\hline Pythium monospermum & $A$ & 0.001 & 0.605 \\
\hline Pythium nodosum & $\mathrm{J}$ & 0.329 & 0.317 \\
\hline Pythium nunn & $\mathrm{J}$ & $<0.001$ & 0.217 \\
\hline Pythium oopapillum & $B$ & 0.132 & 0.596 \\
\hline Pythium orthogonon & $J$ & $<0.001$ & 0.429 \\
\hline Pythium pachycaule & B2 & $<0.001$ & 0.013 \\
\hline Pythium parvum & E2 & 0.014 & 0.607 \\
\hline Pythium periilum & $B$ & $<0.001$ & 0.162 \\
\hline Pythium periplocum & $\mathrm{D}$ & 0.089 & 0.379 \\
\hline Pythium perplexum & $\mathrm{J}$ & $<0.001$ & 0.384 \\
\hline Pythium rostratifingens & $\bar{E}$ & 0.001 & 0.573 \\
\hline Pythium selbyi & E1 & 0.004 & 0.559 \\
\hline Pythium sp. CAL2011f & ND & $<0.001$ & 0.301 \\
\hline Pythium sylvaticum & $\bar{F}$ & $<0.001$ & 0.345 \\
\hline Pythium ultimum & I & $<0.001$ & 0.562 \\
\hline
\end{tabular}

a Species highlighted in bold were significant at $P=0.05$.

b Pythium clades based on taxonomic analysis of the genus Pythium by Lévesque and de Cock (2004) and Robideau et al. (2011). ND indicates a nondescribed sequence or species. used in this study both in incubation temperature and isolation media. Another potentially important finding, Pythium sp. CAL2001f, was detected across environments and a few isolates were directly recovered from soybean seedlings in this study. This species has been previously detected in Ohio using an amplicon sequencing approach but was not isolated from seedlings (Navarro et al. in press) and was also an indicative species for environment DEF25dap in this study. This species has also been reported in other surveys, including in North Dakota (Zitnick-Anderson and Nelson 2015) and the North-Central region of the United States (Rojas et al. 2017a). Due to the number of reports in this and other studies of this putative species and soybean, further studies are needed for this species.

The effects of host genotype on the microbial rhizosphere community have been studied in several other plant hosts, including Arabidopsis (Micallef et al. 2009), barley (Hordeum vulgare) (Bulgarelli et al. 2015), maize (Peiffer et al. 2013), wild mustard (Boechera stricta) (Wagner at al. 2016), sweet potato (Ipomoea batatas) (Marques et al. 2014), and potato (S. tuberosum) (İnceoğlu et al. 2010). Although the effect of genotype on community composition has been explored for these plant species, those studies focused primarily on beneficial microbes; however, little is known about how the abundance, diversity, and community composition of pathogenic species are affected by cultivars. In this study, which is the first to measure the effect of soybean genotype on the abundance of Phytophthora, Phytopythium, and Pythium spp., environment masked the effect of soybean genotype on community composition. For example, soybean genotype explained $<1 \%$ of the overall variance whereas environment explained almost $50 \%$, as calculated using PERMANOVA. However, when the abundance of Phytophthora, Phytopythium, and Pythium spp. was analyzed for each genotype, some effects were observed, and these varied by environment. For instance, the susceptible cultivar Sloan had an overall higher abundance of species of all three genera compared with Kottman and Lorain based on both amplicon sequencing and direct isolation from seedlings. This was expected because Sloan is moderately susceptible to all of the species. For Phytophthora sojae, the presence of Rpslk and Rps $3 a$ plus high levels of partial resistance in Kottman and Rpslc plus high levels of partial resistance in Lorain could explain the reduced abundance in the rhizosphere soil and lower number of isolates recovered via direct isolation, although Kottman tends to be susceptible to more species of Pythium and Phytopythium compared with Lorain based on cup assays (Balk 2014). In addition, the necrotrophic and broad host range for many species of Pythium allows this group of pathogens to proliferate regardless of the plant genotype encountered. This is further emphasized through genomic comparisons because pathogenicity mechanisms between these genera may be associated with the types of effectors and enzymes associated with carbohydrate metabolism (Adhikari et al. 2013). Although unexplored, one possible explanation for the differences in Phytophthora sojae abundance may be associated with different root exudate profiles among the cultivars that may lead to the recruitment of zoospores from specific species within these groups of oomycetes. Soybean root exudate compounds such as flavonoids (Hassan and Mathesius 2012) and soyasaponins (Shiraiwa and Kurosawa 2001; Tsuno et al. 2018) can alter the rhizosphere communities. Soyasaponins are allelochemicals and act as repellents for certain microbes (Waller et al. 1999) while flavonoids are also crucial in the development of rhizobia, as well for the interactions with other plant-growth-promoting bacteria, mycorrhizal fungi, pathogens, and nematodes of soybean (Hassan and Mathesius 2012). Phytophthora sojae is also positively attracted to the isoflavones daidzein and genistein, which are secreted by soybean into the rhizosphere (Morris and Ward 1992; Morris et al. 
TABLE 4

Indicator species (State) values calculated for communities of Pythium, Phytopythium, and Phytophthora spp. associated with 11 environments sampled at 14 days after planting (dap) as well as 2 sites that were sampled 25 dap in Ohio ${ }^{a}$

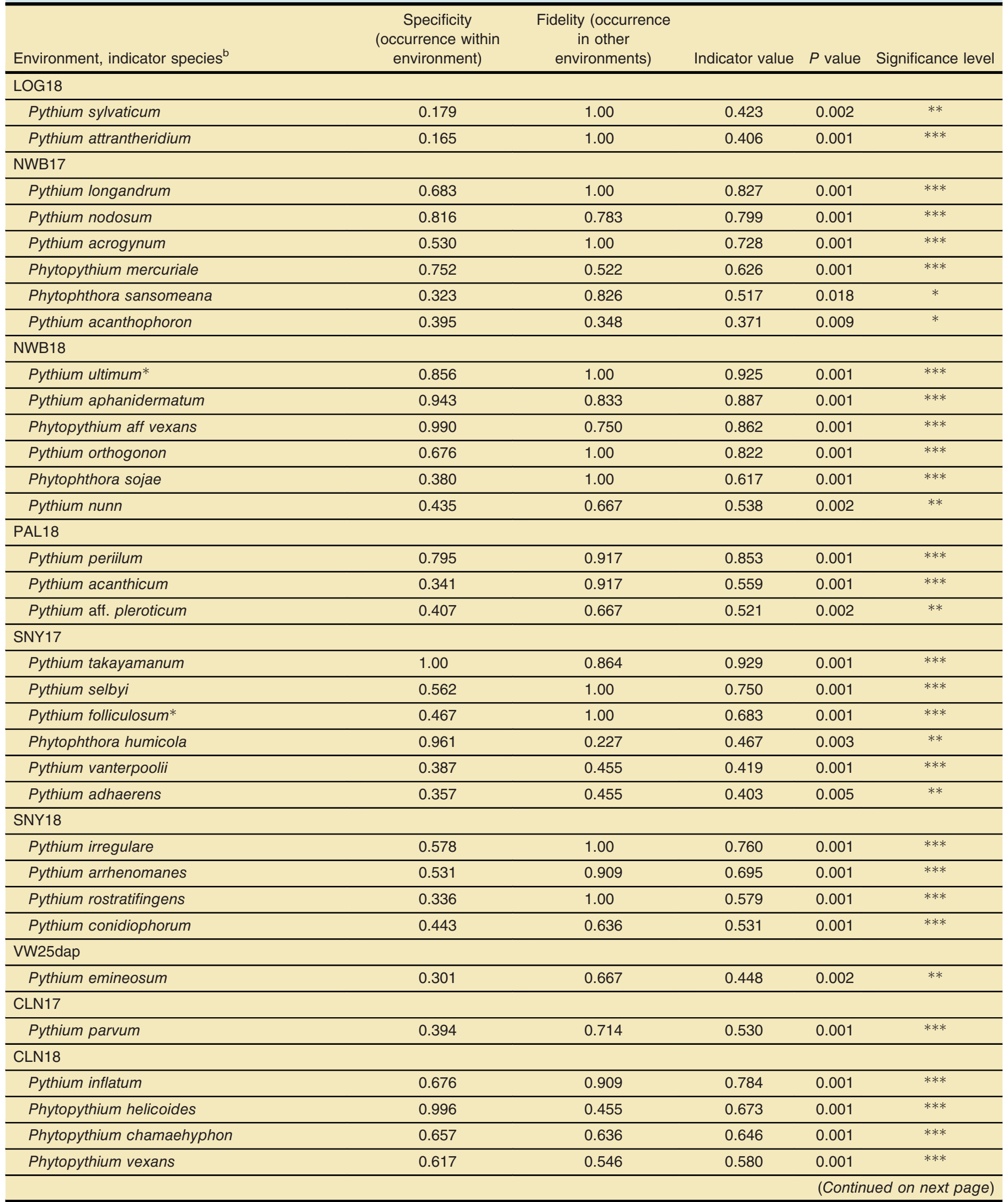

\footnotetext{
a Significance levels were assessed using permutation analysis of variance.

${ }^{b}$ An asterisk $(*)$ next to Pythium ultimum indicates that, based on amplicon sequencing, this name represents both $P$. ultimum var. ultimum and $P$. ultimum var. sporangiiferum; $P$. folliculosum represents seven species within Pythium clade B1, as described by Lévesque and de Cock (2004).
} 
TABLE 4 (Continued from previous page)

\begin{tabular}{|c|c|c|c|c|c|}
\hline Environment, indicator species ${ }^{b}$ & $\begin{array}{c}\text { Specificity } \\
\text { (occurrence within } \\
\text { environment) }\end{array}$ & $\begin{array}{c}\text { Fidelity (occurrence } \\
\text { in other } \\
\text { environments) }\end{array}$ & Indicator value & $P$ value & Significance level \\
\hline Pythium rhizosaccharum & 0.812 & 0.364 & 0.543 & 0.001 & $* * *$ \\
\hline Pythium angustatum & 0.672 & 0.273 & 0.428 & 0.005 & $* *$ \\
\hline Phytophthora rosacearum & 0.694 & 0.182 & 0.355 & 0.028 & $*$ \\
\hline \multicolumn{6}{|l|}{ DAK17 } \\
\hline Pythium perplexum & 0.469 & 0.739 & 0.589 & 0.001 & $* * *$ \\
\hline Pythium periplocum & 0.330 & 0.739 & 0.494 & 0.005 & $* *$ \\
\hline \multicolumn{6}{|l|}{ DEF17 } \\
\hline Pythium chondricola & 0.734 & 0.706 & 0.720 & 0.001 & $* * *$ \\
\hline Pythium aff. hydnosporum & 0.380 & 0.882 & 0.578 & 0.001 & $* * *$ \\
\hline Pythium heterothallicum & 0.198 & 1.00 & 0.445 & 0.004 & $* *$ \\
\hline \multicolumn{6}{|l|}{ DEF25dap } \\
\hline Pythium marinum & 0.797 & 0.913 & 0.853 & 0.001 & $* * *$ \\
\hline Pythium sp. CAL2011f & 0.712 & 1.00 & 0.844 & 0.001 & $* * *$ \\
\hline Pythium oopapillum & 0.505 & 1.00 & 0.710 & 0.001 & $* * *$ \\
\hline Pythium pachycaule & 0.471 & 0.783 & 0.607 & 0.001 & $* * *$ \\
\hline Phytophthora megasperma & 0.489 & 0.348 & 0.412 & 0.006 & $* *$ \\
\hline
\end{tabular}

1998; Tyler et al. 1996). However, other Phytophthora spp. and Pythium irregulare were not attracted to these compounds, indicating that root exudates may play a role in the assembly of communities in the rhizosphere (Morris and Ward 1992). Different cells and root exudates have also been reported to affect the establishment of oomycetes. Goldberg et al. (1989) showed that zoospores of $P$. dissotocum and $P$. catenulatum were chemotactically attracted to border cells of cotton and cucumber, respectively, but were not attracted to the nonhost species. Border cells which are produced on the root tip and that are released into the environment have also been found to attract nematodes (Zhao et al. 2000), bacteria (Hawes et al. 2016), and fungi (Gunawardena and Hawes 2002) and are hypothesized to be a mechanism used by plants to defend against pathogens. The role of root exudates and cell characteristics toward repelling or attracting multiple oomycete species should be further explored.

In this study, the baseline or confirmation that genotype may influence the pathogen communities was addressed. A greater number of isolates was retrieved from the moderately susceptible cultivar Sloan compared with the moderately resistant cultivars Kottman and Lorain. Most importantly, a significant reduction in the abundance of Phytophthora sojae was observed in the rhizosphere soil of Kottman compared with Sloan. Further studies should focus on the profiling of root exudates by these soybean genotypes to better characterize compounds involved in the interaction of oomycetes with soybean. Finally, results from this study will enable the development of more targeted disease management practices by selecting cultivars that can perform better in fields where conducive conditions are encountered.

This study shows that species of Phytophthora, Phytopythium, and Pythium should be monitored on a regular basis because populations can change and different species can emerge. We also generated a collection of isolates obtained from symptomatic and asymptomatic soybean seedlings from 11 different environments across Ohio, including isolates of the undescribed Pythium sp. CAL2011f. With this understanding of the diversity of the community composition among these environments, microbial plant engineering has been proposed as a possible breeding strategy to help select beneficial microbes or repel pathogens and, thus, improve yields (Bakker et al. 2012; Quiza et al. 2015; Oger et al. 2004; Pérez-Jaramillo et al. 2017; Ryan et al. 2009). One means to explore the effectiveness of this approach is by deciphering the communities enhanced or reduced in cultivars that exhibited diverse levels and types of resistance.

Using an amplicon sequencing approach, this study revealed that environment, which includes a combination of previous production practices, temperature, and precipitation, was the primary factor driving community composition. Plant genotype affected the abundance of Phytophthora sojae, a hemibiotroph, and Pythium pachycaule (eight species in Pythium clade B2) in the soybean seedling rhizosphere whereas it had no effect on the abundance the Pythium or Phytopythium spp., which are necrotrophs and generalists, that were directly isolated or detected in the rhizospheric soil during this study. In addition, this study enabled the detection of Pythium periilum OTU for the first time in Ohio and the isolation of the undescribed Pythium sp. CAL2011f from soybean seedlings.

\section{ACKNOWLEDGMENTS}

We thank S. Veney, G. H. Lara, and D. Veney for technical assistance during sample processing and collecting field data; the field research staff at OSU Northwest Agricultural Research 
Station and Snyder Farm along with our farmer cooperators who helped with this project; F. D. Lana for assistance in data visualization in R; and P. Paul for assistance in statistical analysis.

\section{LITERATURE CITED}

Adhikari, B. N., Hamilton, J. P., Zerillo, M. M., Tisserat, N., Lévesque, C. A., and Buell, R. 2013. Comparative genomics reveals insight into virulence strategies of plant pathogenic Oomycetes. PLoS One 8:e75072.

Anderson, M. J. 2001. A new method for non-parametric multivariate analysis of variance. Aust. Ecol. 26:32-46.

Anderson, T., and Buzzell, R. 1982. Efficacy of metalaxyl in controlling Phytophthora root and stalk rot of soybean cultivars differing in field tolerance. Plant Dis. 66:1144-1145.

Bahrenfus, J. B., and Fehr, W. R. 1980. Registration of Sloan soybean. Crop Sci. 20:673.

Bakker, M. G., Manter, D. K., Sheflin, A. M., Weir, T. L., and Vivanco, J. M. 2012. Harnessing the rhizosphere microbiome through plant breeding and agricultural management. Plant Soil 360:1-13.

Bakker, M. G., Moorman, T. B., Kaspar, T. C., and Manter, D. K. 2017. Isolation of cultivation-resistant oomycetes, first detected as amplicon sequences, from roots of herbicide-terminated winter rye. Phytobiomes J. $1: 24-35$.

Balk, C. S. 2014. Assessment of resistance in soybean to Pythium ultimum and sensitivity of Ohio's diverse Pythium species towards metalaxyl. M.S thesis, The Ohio State University, Columbus, OH, U.S.A.

Bengtsson-Palme, J., Ryberg, M., Hartmann, M., Branco, S., Wang, Z., Godhe, A., De Wit, P., Sánchez-García, M., Ebersberger, I., de Sousa, F., Amend, A., Jumpponen, A., Unterseher, M., Kristiansson, E., Abarenkov, K., Bertrand, Y. J. K., Sanli, K., Eriksson, K. M., Vik, U., Veldre, V., and Nilsson, R. H. 2013. Improved software detection and extraction of ITS1 and ITS2 from ribosomal ITS sequences of fungi and other eukaryotes for analysis of environmental sequencing data. Methods Ecol. Evol. 4:914-919.

Bradley, C. A. 2008. Effect of fungicide seed treatments on stand establishment, seedling disease, and yield of soybean in North Dakota. Plant Dis. 92:120-125.

Broders, K. D., Lipps, P. E., Paul, P. A., and Dorrance, A. E. 2007. Characterization of Pythium spp. associated with corn and soybean seed and seedling disease in Ohio. Plant Dis. 91:727-735.

Broders, K. D., Wallhead, M. W., Austin, G. D., Lipps, P. E., Paul, P. A., Mullen, R. W., and Dorrance, A. E. 2009. Association of soil chemical and physical properties with Pythium species diversity, community composition, and disease incidence. Phytopathology 99:957-967.

Bulgarelli, D., Garrido-Oter, R., Münch, P. C., Weiman, A., Dröge, J., Pan, Y., McHardy, A. C., and Schulze-Lefert, P. 2015. Structure and function of the bacterial root microbiota in wild and domesticated barley. Cell Host Microbe 17:392-403.

Coffua, L. S., Veterano, T., Clipman, S. J., Mena-Ali, J. I., and Blair, J. E. 2016. Characterization of Pythium spp. associated with asymptomatic soybean in southeastern Pennsylvania. Plant Dis. 100:1870-1879.

Cooke, D. E. L., Drenth, A., Duncan, J. M., Wagels, G., and Brasier, C. M. 2000. A molecular phylogeny of Phytophthora and related oomycetes. Fungal Genet. Biol. 30:17-32.

Cooke, D. E. L., and Duncan, J. M. 1997. Phylogenetic analysis of Phytophthora species based on ITS1 and ITS2 sequences of the ribosomal RNA gene repeat. Mycol. Res. 101:667-677.

De Cáceres, M., and Legendre, P. 2009. Associations between species and groups of sites: Indices and statistical inference. Ecology 90:3566-3574.

de Cock, A. W., Lodhi, A. M., Rintoul, T. L., Bala, K., Robideau, G. P., Abad, Z. G., Coffey, M. D., Shahzad, S., and Lévesque, C. A. 2015. Phytopythium: Molecular phylogeny and systematics. Persoonia 34:25-39.

Dorrance, A. E., Berry, S. A., Anderson, T. R., and Meharg, C. 2008. Isolation, storage, pathotype characterization, and evaluation of resistance for Phytophthora sojae in soybean. Plant Health Prog. 9. https://doi.org/ 10.1094/PHP-2008-0118-01-DG

Dorrance, A. E., Berry, S. A., Bowen, P., and Lipps, P. E. 2004. Characterization of Pythium spp. from three Ohio fields for pathogenicity on corn and soybean and metalaxyl sensitivity. Plant Health Prog. 5. https://doi.org/10.1094/PHP-2004-0202-01-RS

Dorrance, A. E., Kurle, J., Robertson, A. E., Bradley, C. A., Giesler, L., Wise, K., and Concibido, V. C. 2016. Pathotype diversity of Phytophthora sojae in eleven states in the United States. Plant Dis. 100:1429-1437.
Dorrance, A. E., Mills, D., Robertson, A. E., Draper, M. A., Giesler, L., and Tenuta, A. 2007. Phytophthora root and stem rot of soybean. The Plant Health Instructor. https://www.apsnet.org/edcenter/disandpath/oomycete/ pdlessons/Pages/PhytophthoraSojae.aspx

Dorrance, A. E., Robertson, A. E., Cianzo, S., Giesler, L. J., Grau, C. R., Draper, M. A., Tenuta, A. U., and Anderson, T. R. 2009. Integrated management strategies for Phytophthora sojae combining host resistance and seed treatment. Plant Dis. 93:875-882.

Edgar, R. C. 2010. Search and clustering orders of magnitude faster than BLAST. Bioinformatics 26:2460-2461.

Edgar, R. C. 2013. UPARSE: Highly accurate OTU sequences from microbial amplicon reads. Nat. Methods 10:996-998.

Edgar, R. C., and Flyvbjerg, H. 2015. Error filtering, pair assembly and error correction for next-generation sequencing reads. Bioinformatics 31:3476-3482.

Ellis, M. L., McHale, L. K., Paul, P. A., St. Martin, S. K., and Dorrance, A. E. 2013. Soybean germplasm resistant to Pythium irregulare and molecular mapping of resistance quantitative trait loci derived from the soybean accession PI 424354. Crop Sci. 53:1008-1021.

Erwin, D. C., and Ribeiro, O. K. 1996. Isolation and detection of Phytophthora. Pages 8-41 in: Phytophthora Diseases Worldwide. American Phytopathological Society, St. Paul, MN, U.S.A.

Eyre, M. M. 2016. Characterizing the effect of increased phosphorus and potassium on seedling diseases and sudden death syndrome of soybean in Ohio. M.S. thesis, The Ohio State University, Columbus, OH, U.S.A.

Fehr, W. R., and Caviness, C. E. 1977. Stages of Soybean Development. Special Report 87. Iowa State University, Ames, IA, U.S.A.

Firáková, S., Śturdíková, M., and Múčková, M. 2007. Bioactive secondary metabolites produced by microorganisms associated with plants. Biologia 62:251-257.

Garzón, C. D., Geiser, D. M., and Moorman, G. W. 2005. Diagnosis and population analysis of Pythium species using AFLP fingerprinting. Plant Dis. 89:81-89.

Goldberg, N., Hawes, M. C., and Stanghellini, M. 1989. Specific attraction to and infection of cotton root cap cells by zoospores of Pythium dissotocum. Can. J. Bot. 67:1760-1767.

Grau, C. R., Dorrance, A. E., Bond, J., and Russin, J. 2004. Fungal diseases Pages 679-763 in: Soybeans: Improvement, Production and Uses, Third Ed. H. R. Boerma and J. E. Specht, eds. Agronomy Monograph No. 16. American Society of Agronomy, Crop Science Society of America, Soil Science Society of America, Madison, WI, U.S.A.

Gunawardena, U., and Hawes, M. C. 2002. Tissue specific localization of root infection by fungal pathogens. Mol. Plant-Microbe Interact. 15:1128-1136.

Hansen, E. M., Wilcox, W. F., Reeser, P. W., and Sutton, W. 2009. Phytophthora rosacearum and $P$. sansomeana, new species segregated from the Phytophthora megasperma "complex". Mycologia 101:129-135.

Hassan, S., and Mathesius, U. 2012. The role of flavonoids in root-rhizosphere signaling opportunities and challenges for improving plant-microbe interactions. J. Exp. Bot. 63:3429-3444.

Hawes, M., Allen, C., Turgeon, G., Rivera, G., Tran, T., Huskey, D., and Xiong, Z. 2016. Root border cells and their role in plant defense. Annu. Rev. Phytopathol. 54:143-161.

Hyde, K. D., Nilsson, R. H., Alias, S. A., Ariyawansa, H. A., Blair, J. E., Cai, L., de Cock, W. A. M., Dissanayake, A. J., Glockling, S. L., Goonasekara, I. D., Gorczak, M., Hahn, M., Jayawardena, R. S., van Kan, J. A. L., Laurence, M. H., Lévesque, C. A., Li, X., Liu, J.-K., Maharachchikumbura, S. S. N., Manamgoda, D. S., Martin, F. N., McKenzie, E. H. C., McTaggart, A. R., Mortimer, P. E., Nair, P. V. R., Pawłowska, J., Rintoul, T. L., Shivas, R. G., Spies, C. F. J., Summerell, B. A., Taylor, P. W. J., Terhem, R. B., Udayanga, D., Vighefi, N., Walther, G., Wilk, M., Wrzosek, M., Xu, J.-C., Yan, J., and Zhou, N. 2014. One stop shop: Backbones trees for important phytopathogenic genera: I. Fungal Divers. 67:21-125.

İnceoğlu, Ö., Salles, J. F., van Overbeek, L., and van Elsas, J. D. 2010. Effects of plant genotype and growth stage on the betaproteobacterial communities associated with different potato cultivars in two fields. Appl. Environ. Microbiol. 76:3675-3684.

Jiang, Y. N., Haudenshield, J. S., and Hartman, G. L. 2012. Characterization of Pythium spp. from soil samples in Illinois. Can. J. Plant Pathol. 34: 448-454.

Klepadlo, M., Balk, C. S., Vuong, T. D., Dorrance, A. E., and Nguyen, H. T. 2019. Molecular characterization of genomic regions for resistance to Pythium ultimum var. ultimum in soybean cultivar Magellan. Theor. Appl. Genet. 132:405-417. 
Kroon, L. P. N. M., Brouwer, H., de Cock, A. W. A. M., and Govers, F 2012. The genus Phytophthora Anno 2012. Phytopathology 102:348-364.

Kruskal, W. H., and Wallis, W. A. 1952. Use of ranks in one-criterion variance analysis. J. Am. Stat. Assoc. 47:583-621.

Lévesque, C. A., and de Cock, A. W. 2004. Molecular phylogeny and taxonomy of the genus Pythium. Mycol. Res. 108:1363-1383.

Mammadov, J., Buyyarapu, R., Guttikonda, S. K., Parliament, K., Abdurakhomonav, I. Y., and Kumpatla, S. P. 2018. Wild relatives of maize, rice, cotton, and soybean: Treasure troves for tolerance to biotic and abiotic stresses. Front. Plant Sci. 9:886.

Marques, J. M., da Silva, T. F., Vollu, R. E., Blank, A. F., Ding, G. C., Seldin, L., and Smalla, K. 2014. Plant age and genotype affect the bacterial community composition in the tuber rhizosphere of field-grown sweet potato plants. FEMS Microbiol. Ecol. 88:424-435.

Martin, F. N., and Loper, J. E. 1999. Soilborne plant diseases caused by Pythium spp.: Ecology, epidemiology, and prospects for biological control. Crit. Rev. Plant Sci. 18:111-181.

Matthiesen, R. L., Ahmad, A. A., and Robertson, A. E. 2016. Temperature affects aggressiveness and fungicide sensitivity of four Pythium spp. that causes soybean and corn damping off in Iowa. Plant Dis. 100:583-591.

McMurdie, P. J., and Holmes, S. 2013. Phyloseq: An R Package for reproducible interactive analysis and graphics of microbiome census data. PLoS One 8:e61217.

Mendes, L., Kuramae, E., Navarrete, A., van Veen, J., and Tsai, S. 2014. Taxonomical and functional microbial community selection in soybean rhizosphere. ISME J. 8:1577-1587.

Mendes, R., Garbeva, P., and Raaijmakers, J. M. 2013. The rhizosphere microbiome: Significance of plant beneficial, plant pathogenic, and human pathogenic microorganisms. FEMS Microbiol. Rev. 37:634-663.

Mendes, R., Kruijt, M., de Bruijn, I., Dekkers, E., van der Voort, M., Schneider, J. H., Piceno, Y. M., DeSantis, T. Z., Andersen, G. L., Bakker, P. A., and Raaijmakers, J. M. 2011. Deciphering the rhizosphere microbiome for disease-suppressive bacteria. Science 332:1097-1100.

Micallef, S. A., Shiaris, M. P., and Colon-Carmona, A. 2009. Influence of Arabidopsis thaliana accessions on rhizobacterial communities and natural variation in root exudates. J. Exp. Bot. 60:1729-1742.

Mideros, S., Nita, M., and Dorrance, A. E. 2007. Characterization of components of partial resistance, Rps2, and root resistance to Phytophthora sojae in soybean. Phytopathology 97:655-662.

Morris, P. F., Bone, E., and Tyler, B. M. 1998. Chemotropic and contact responses of Phytophthora sojae hyphae to soybean isoflavonoids and artificial substrates. Plant Physiol. 117:1171-1178.

Morris, P. F., and Ward, E. W. B. 1992. Chemoattraction of zoospores of the soybean pathogen Phytophthora sojae by isoflavones. Physiol. Mol. Plant Pathol. 40:17-22.

Navarro, K. A., Wijeratne, S., Culman, S. W., Benitez, M.-S., and Dorrance, A. E. The effect of incubation temperature on the species composition of Phytophthora, Phytopythium, and Pythium communities associated with soybean. Phytobiomes J. In press.

Oger, P., Mansouri, H., Nesme, X., and Dessaux, Y. 2004. Engineering root exudation of lotus toward the production of two novel carbon compounds leads to the selection of distinct microbial populations in the rhizosphere. Microb. Ecol. 47:96-103.

Oksanen, J. F., Blanchet, G., Friendly, M., Kindt, R., Legendre, P., McGlinn, D., Minchin, P. R., and O'Hara, R. B., Simpson, G. L., Solymos, P., Stevens, M. H. H., Szoecs, E., and Wagner, H. 2019. Vegan: Community Ecology Package. R package version 2.5-5. https://cran.r-project.org/web/ packages/vegan/index.html

Paulson, J. N., Stine, O. C., and Corroda-Bravo, H. 2013. Differential abundance analysis for microbial marker-gene survey. Nat. Methods 10:1200-1202.

Peiffer, J. A., Spor, A., Koren, O., Jin, Z., Green, S., Dangl, J. L., Buckler, E. S., and Ley, R. E. 2013. Diversity and heritability of the maize rhizosphere microbiome under field conditions. Proc. Natl. Acad. Sci. U.S.A. 110:6548-6553.

Pérez-Jaramillo, J. E., Carrión, V. J., Bosse, M., Ferrão, L. F., de Hollander, M., Garcia, A. A., Ramírez, C. A., Mendes, R., and Raaijmakers, J. M. 2017. Linking rhizosphere microbiome composition of wild and domesticated Phaseolus vulgaris to genotypic and root phenotypic traits. ISME J. 11:2244-2257.

Pérez-Jaramillo, J. E., de Hollander, M., Ramírez, C. A., Mendes, R., Raaijmakers, J. M., and Carrión, V. J. 2019. Deciphering rhizosphere microbiome assembly of wild and modern common bean (Phaseolus vulgaris) in native and agricultural soils from Colombia. Microbiome 7:114.

Pérez-Jaramillo, J. E., Mendes, R., and Raaijmakers, J. M. 2016. Impact of plant domestication on rhizosphere microbiome assembly and functions. Plant Mol. Biol. 90:635-644.

Philippot, L., Raaijmakers, J. M., Lemanceau, P., and van der Putten, W. H. 2013. Going back to the roots: The microbial ecology of the rhizosphere. Nat. Rev. Microbiol. 11:789-799.

Quiza, L., St-Arnaud, M., and Yergeau, E. 2015. Harnessing phytomicrobiome signaling for rhizosphere microbiome engineering. Front. Plant Sci. 6:507.

Radmer, L., Anderson, G., Malvick, D. M., Kurle, J. E., Rendahl, A., and Mallik, A. 2017. Pythium, Phytophthora, and Phytopythium spp. associated with soybean in Minnesota, their relative aggressiveness on soybean and corn, and their sensitivity to seed treatment fungicides. Plant Dis. 101:62-72.

R Core Team. 2018. R: A Language and Environment for Statistical Computing. R Foundation for Statistical Computing, Vienna, Austria. https://www.R-project.org/

Redekar, N. R., Eberhart, J. L., and Parke, J. L. 2019. Diversity of Phytophthora, Pythium and Phytopythium species in recycled irrigation water in a container nursery. Phytobiomes J. 3:31-45.

Reeser, P. W., Scott, D. H., and Ruhl, D. E. 1991. Recovery of race nonclassifiable Phytophthora megasperma f. sp. glycinea from soybean roots in Indiana in 1990. Phytopathology 81:1201.

Robideau, G. P., de Cock, A. W., Coffey, M. D., Voglmayr, H., Brouwer, H., Bala, K., Chitty, D. W., Désaulniers, N., Eggertson, Q. A., Gachon, C. M., Hu, C. H., Küpper, F. C., Rintoul, T. L., Sarhan, E., Verstappen, E. C., Zhang, Y., Bonants, P. J., Ristaino, J. B., and Lévesque, C. A. 2011. DNA barcoding of oomycetes with cytochrome c oxidase subunit I and internal transcribed spacer. Mol. Ecol. Resour. 11:1002-1011.

Rod, K. S., Walker, D. R., and Bradley, C. 2018. Evaluation of major ancestors of North American soybean cultivars for resistance to three Pythium species that cause seedling blight. Plant Dis. 102:2241-2252.

Rojas, J. A., Jacobs, J. L., Napieralski, S., Karaj, B., Bradley, C. A., Chase, T., Esker, P. D., Giesler, L. J., Jardine, D. J., Malvick, D. K., Markell, S. G., Nelson, B. D., Robertson, A. E., Rupe, J. C., Smith, D. L., Sweets, L. E., Tenuta, A. U., Wise, K. A., and Chilvers, M. I. 2017a. Oomycete species association with soybean seedlings in North America-Part I: Identification and pathogenicity characterization. Phytopathology 107:280-292.

Rojas, J. A., Jacobs, J. L., Napieralski, S., Karaj, B., Bradley, C. A., Chase, T., Esker, P. D., Giesler, L. J., Jardine, D. J., Malvick, D. K., Markell, S. G., Nelson, B. D., Robertson, A. E., Rupe, J. C., Smith, D. L., Sweets, L. E., Tenuta, A. U., Wise, K. A., and Chilvers, M. I. 2017b. Oomycete species associated with soybean seedlings in North America-Part II: Diversity and ecology in relation to environmental and edaphic factors. Phytopathology 107:293-304.

Rojas, J. A., Witte, A., Noel, Z. A., Jacobs, J. L., and Chilvers, M. I. 2019. Diversity and characterization of oomycetes associated with corn seedlings in Michigan. Phytobiomes J. 3:224-234.

Rosso, M. L., Rupe, J. C., Chen, P., and Mozzoni, L. A. 2008. Inheritance and genetic mapping of resistance to damping-off caused by Pythium aphanidermatum in 'Archer' soybean. Crop Sci. 48:2215-2222.

Rupe, J. C., Rothrock, C. S., Bates, G., Rosso, M. L., Avanzato, M. V., and Chen, P. 2011. Resistance to Pythium seedling disease in soybean. Pages 261-276 in: Soybean Molecular Aspects of Breeding. A. Sudaric, ed. Intech, Rjeka, Croatia.

Ryan, P. R., Dessaux, Y., Thomashow, L. S., and Weller, D. M. 2009. Rhizosphere engineering and management for sustainable agriculture. Plant Soil 321:363-383.

Schmitthenner, A. F. 1985. Problems and progress in control of Phytophthora root rot of soybean. Plant Dis. 69:362-368.

Schroeder, K. L., Martin, F. N., de Cock, A. W. A. M., Lévesque, C. A., Spies, C. F. J., Okubara, P. A., and Paulitz, T. C. 2013. Molecular detection and quantification of Pythium species: Evolving taxonomy, new tools, and challenges. Plant Dis. 97:4-20.

Scott, K., Balk, C., Veney, D., McHale, L. K., and Dorrance, A. E. 2019. Quantitative disease resistance loci towards Phytophthora sojae and three species of Pythium in six soybean nested association mapping populations. Crop Sci. 59:605-623.

Serrano, M., and Robertson, A. E. 2018. The effect of cold stress on damping-off of soybean caused by Pythium sylvaticum. Plant Dis. 102:2194-2200. 
Shi, S., Chang, J., Tian, L., Nasir, F., Ji, L., Li, X., and Tian, C. 2019. Comparative analysis of the rhizomicrobiome of the wild versus cultivated crop: Insights from rice and soybean. Arch. Microbiol. 201:879-888.

Shiraiwa, M., and Kurosawa, Y. 2001. Purification and characterization of glucuronosyltransferase for the elucidation of physiological role of saponin in soybean plant and the breeding of a value-added soybean variety. Soy Protein Res. Jpn. 4:1-10.

Slaminko, T. L., Bowen, C. R., and Hartman, G. L. 2010. Multi-year evaluation of commercial soybean cultivars for resistance to Phytophthora sojae. Plant Dis. 94:368-371.

Smalla, K., Wieland, G., Buchner, A., Zock, A., Parzy, J., Kaiser, S., Roskot, N., Heuer, H., and Berg, G. 2001. Bulk and rhizosphere soil bacterial communities studied by denaturing gradient gel electrophoresis: Plantdependent enrichment and seasonal shifts revealed. Appl. Environ. Microbiol. 67:4742-4751.

Stasko, A. K., Wickramasinghe, D., Nauth, B. J., Acharya, B., Ellis, M. L., Taylor, C. G., McHale, L. K., and Dorrance, A. E. 2016. High-density mapping of resistance QTL toward Phytophthora sojae, Pythium irregulare, and Fusarium graminearum in the same soybean population. Crop Sci. 56:2476-2492.

St. Martin, S. K., Mills, G. R., Fioritto, R. J., McIntyre, S. A., Schmitthenner, A. F., Dorrance, A. E., and Cooper, R. L. 2021. Registration of 'Kottman' soybean. Crop Sci. 41:590-591.

Tsuno, Y., Fujimatsu, T., Endo, K., Sugiyama, A., and Yazaki, K. 2018. Soyasaponins: A new class of root exudates in soybean (Glycine max). Plant Cell Physiol. 59:366-375.

Tyler, B. M., Wu, M., Wang, J., Cheung, W., and Morris, P. F. 1996. Chemotactic preferences and strain variation in the response of Phytophthora sojae zoospores to host isoflavones. Appl. Environ. Microbiol. 62:2811-2817.

Tzean, S. S., and Estey, R. H. 1981. Species of Phytophthora and Pythium as nematode-destroying fungi. J. Nematol. 13:160-163.

Urrea, K., Rupe, J., Chen, P., and Rothrock, C. S. 2017. Characterization of seed rot resistance to Pythium aphanidermatum in soybean. Crop Sci. 57:1394-1403
Uzuhashi, S., Tojo, M., and Kakishima, M. 2010. Phylogeny of the genus Pythium and description of new genera. Mycoscience 51:337-365.

van der Plaats-Niterink, A. J. 1981. Monograph of the genus Pythium. Stud. Mycol. 21:1-242.

Vargas, A. 2018. Management of Seedling Diseases caused by Oomycetes, Phytophthora spp., Phytopythium spp. and Pythium spp. using Seed Treatment in Ohio. M.S. thesis, The Ohio State University, Columbus, OH, U.S.A.

Wagner, M. R., Lundberg, D. S., Del Rio, T. G., Tringe, S. G., Dangl, J. L., and Mitchell-Olds, T. 2016. Host genotype and age shape the leaf and root microbiomes of a wild perennial plant. Nat. Commun. 7:12151.

Waller, G. R., Yang, C. F., Chen, L. F., Su, C. H., Liou, R. M., Wu, S. C., Young, C. C., Lee, M. R., Lee, J. S., Cheng, C. S., Chou, C. H., and Kim, D. 1999. Saponins produced during the life cycle of mungbeans and their role as allelochemicals. Stud. Plant Sci. 6:105-130.

Waterhouse, G. M. 1967. Key to Pythium Pringsheim. Mycol. Pap. no. 109. Commonwealth Mycological Institute, Kew, England.

White, T. J., Bruns, T., Lee, S., and Taylor, J. 1993. Amplification and direct sequencing of fungal ribosomal RNA genes for phylogenetics. Pages 315322 in: PCR Protocols: A Guide to Methods and Applications. M. A. Innis, D. H. Gelfand, J. J. Sninsky, and T. J. White, eds. Humana Press, Totowa, NJ, U.S.A.

Wingett, S. W., and Andrews, S. 2018. FastQ Screen: A tool for multigenome mapping and quality control. F1000Res. 7:1338.

Zelaya-Molina, L. X., Ellis, M. L., Berry, S. A., and Dorrance, A. E. 2010. First report of Phytophthora sansomeana causing wilting and stunting on corn in Ohio. Plant Dis. 94:125.

Zelaya-Molina, L. X., Ortega, M. A., and Dorrance, A. E. 2011. Easy and efficient protocol for oomycete DNA extraction suitable for population genetic analysis. Biotechnol. Lett. 33:715-720.

Zhao, X., Schmidt, M., and Hawes, M. C. 2000. Species-dependent effects of border cell and root tip exudates on nematode behavior. Phytopathology 90:1239-1245.

Zitnick-Anderson, K. K., and Nelson, B. D. 2015. Identification and pathogenicity of Pythium on soybean in North Dakota. Plant Dis. 99:31-38. 